\title{
Status of the Porsild's Bryum (Bryum porsildii) in Alberta
}

Fish \& Widilife Division

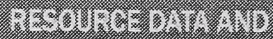

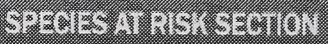

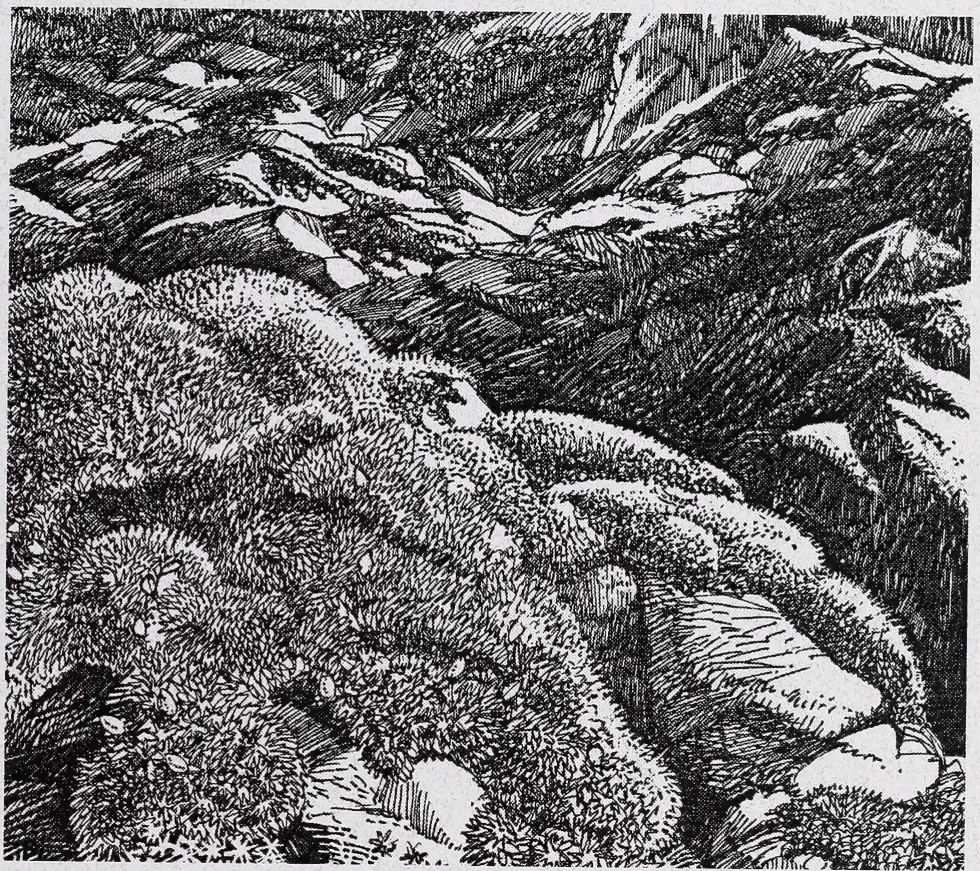

Alberta Wildlife Status Report No. 59

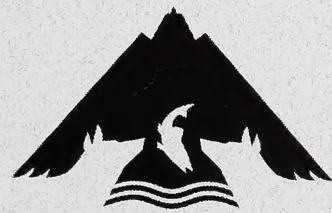

Alberta Conservation Association 



\title{
Status of the Porsild's Bryum (Bryum porsildii) in Alberta
}

\author{
Prepared for: \\ Alberta Sustainable Resource Development (SRD) \\ Alberta Conservation Association (ACA)
}

\section{Prepared by: \\ Jennifer Doubt}

This report has been reviewed, revised, and edited prior to publication.

It is an SRD/ACA working document that will be revised and updated periodically.

Alberta Wildlife Status Report No. 59

June 2006

Published By:

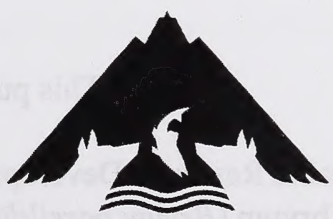

Alberta Conservation Association 


$$
\text { Publication No. T/104 }
$$

ISBN: 0-7785-4540-7 (Printed Edition)

ISBN: 0-7785-4541-5 (On-line Edition)

ISSN: 1206-4912 (Printed Edition)

ISSN: 1499-4682 (On-line Edition)

Series Editors: Sue Peters, Robin Gutsell, Nyree Sharp and Lisa Matthias Illustrations: Brian Huffman

Maps: Jane Bailey and Nicole Hopkins

For copies of this report, visit our web site at:

http://www.srd.gov.ab.ca/fw/speciesatrisk/

and click on "Detailed Status"

OR

Contact:

Information Centre - Publications

Alberta Sustainable Resource Development

Main Floor, Great West Life Building 9920 - 108 Street

Edmonton, Alberta, Canada T5K 2M4

Telephone: (780) 422-2079

This publication may be cited as:

Alberta Sustainable Resource Development and Alberta Conservation Association. 2006. Status of the Porsild's bryum (Bryum porsildii) in Alberta. Alberta Sustainable Resource Development, Wildlife Status Report No. 59, Edmonton, AB. 30 pp. 


\section{PREFACE}

Every five years, the Fish and Wildlife Division of Alberta Sustainable Resource Development reviews the general status of wildlife species in Alberta. These overviews, which have been conducted in 1991 (The Status of Alberta Wildlife), 1996 (The Status of Alberta Wildlife) and 2000 (The General Status of Alberta Wild Species 2000), assign individual species "ranks" that reflect the perceived level of risk to populations that occur in the province. Such designations are determined from extensive consultations with professional and amateur biologists, and from a variety of readily available sources of population data. A key objective of these reviews is to identify species that may be considered for more detailed status determinations.

The Alberta Wildlife Status Report Series is an extension of the general status exercise, and provides comprehensive current summaries of the biological status of selected wildlife species in Alberta. Priority is given to species that are At Risk or May Be At Risk in the province, that are of uncertain status (Undetermined), or that are considered to be at risk at a national level by the Committee on the Status of Endangered Wildlife in Canada (COSEWIC).

Reports in this series are published and distributed by the Alberta Conservation Association and the Fish and Wildlife Division of Alberta Sustainable Resource Development. They are intended to provide detailed and up-to-date information that will be useful to resource professionals for managing populations of species and their habitats in the province. The reports are also designed to provide current information that will assist Alberta's Endangered Species Conservation Committee in identifying species that may be formally designated as Endangered or Threatened under Alberta's Wildlife Act. To achieve these goals, the reports have been authored and/or reviewed by individuals with unique local expertise in the biology and management of each species. 


\section{EXECUTIVE SUMMARY}

Porsild's bryum (Bryum porsildii) is a nationally and globally rare, rock-dwelling moss that forms brilliant, rich green cushions on wet, generally unstable calcareous rock. It was first documented in Alberta in 1828 by botanist-explorer Thomas Drummond at its type locality (the site from which the specimen used to first describe the species was collected) in Jasper National Park. Porsild's bryum was next found in Alberta over a century later in 1966, and eight localities have been documented to date. Although the original site has not been relocated, all other known Alberta populations (one in Evan-Thomas Provincial Recreation Area, four in and around Whitehorse Wildland Park, and two in Willmore Wilderness area) are extant.

Canada's largest documented provincial population of Porsild's bryum, both in terms of extent of occurrence and area occupied, is found in Alberta, where two populations are known in Willmore Wilderness, four populations are known from the Whitehorse Creek area, near Cadomin, and one population is known from Kananaskis Country. Additional Canadian occurrences are documented in Nunavut, British Columbia and Newfoundland. Globally, the species also occurs in the United States (Alaska, Montana, Wyoming, Colorado, Michigan), and around the northern hemisphere in Siberia, Kazakhstan and central Asia. Although Porsild's bryum occurs across a wide area, it is disjunct and highly localized throughout its range.

Although the presence of some Alberta populations of Porsild's bryum has proven stable for up to 38 years, natural disturbances characteristic of the species' preferred habitat can lead to frequent, often broad fluctuations in local abundance. Natural frost disturbance recently reduced what was Canada's largest population (in Newfoundland), from hundreds of colonies to just nine. Research has shown that Porsild's bryum is at least partly physiologically limited to its extremely specialized habitat type.

All but one of the known Alberta populations of Porsild's bryum occur within the boundaries of provincial parks, placing their habitats within provincial jurisdiction and providing some degree of protection from urban and industrial disturbance. However, all or part of most populations lie in close proximity to roads and trails and are subject to varying intensities of recreational traffic. In the most extreme case, Porsild's bryum grows within a campsite on a rock that is periodically used by campers as shelter for picnic tables or campfires. Two populations also lie within $100 \mathrm{~m}$ of a newly constructed, busy coal mine haul road. Localized or general (e.g., climate-related) changes to hydrology, water chemistry and turbidity would also pose a considerable risk.

Porsild's bryum is a poor transplant candidate because of low transplant viability and insufficient understanding of its ecological requirements. Past researchers have emphasized the importance of preserving existing populations and habitat. Additional research, including ecological studies of existing populations and surveys for additional occurrences, is recommended. 


\section{ACKNOWLEDGEMENTS}

Information compiled in COSEWIC's national status report on Porsild's bryum (COSEWIC 2003) forms the foundation of this report. The author of the COSEWIC report, Natalie Cleavitt (currently of Cornell University), also studied the species for her doctoral thesis, discovering and documenting several Alberta populations in the process. Cleavitt was instrumental in the preparation of this provincial status report, not only through her excellent work and publications on Porsild's bryum, but also by providing detailed directions to Alberta populations and making herself consistently available to discuss her methods and the species' biology.

Thanks are also extended to the Parks and Protected Areas Division of Alberta Community Development for permission to access and sample populations of Porsild's bryum in Whitehorse Creek Provincial Recreation Area, Whitehorse Wildland Park and Evan-Thomas Provincial Recreation Area. Elk Valley Coal permitted access to the Whitehorse Creek area for sampling during the construction of the Cheviot Mine haul road, and the fieldwork along the road was facilitated by Keith Streeter and Greg Ross.

I gratefully acknowledge the field assistance of Karl Soopalu. Larry and Nellie Chapman of Packsaddle Adventures outfitted and guided access by horse to Whitehorse Falls and Drummond Creek. Nyree Sharp's (Alberta Conservation Association) patient, proficient administration and editing are also very much appreciated, as are the contributions of René Belland (University of Alberta, Devonian Botanic Garden), Alison Dinwoodie (volunteer steward for Whitehorse Wildland Park), John Rintoul (Alberta Natural Heritage Information Centre), and Dale Vitt (Department of Plant Biology, Southern Illinois University), with whom I communicated with respect to the report.

Preparation of this report was funded by the Alberta Conservation Association and the Fish and Wildlife Division of Alberta Sustainable Resource Development. 
Digitized by the Internet Archive in 2016 


\section{TABLE OF CONTENTS}

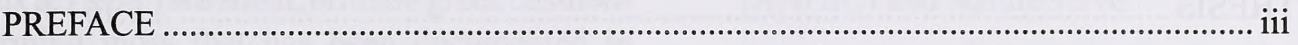

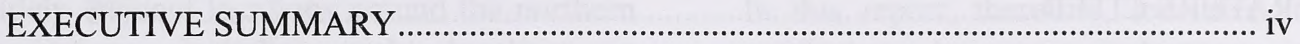

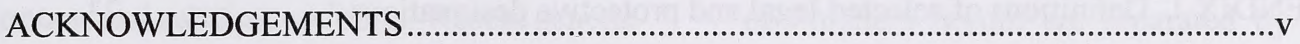

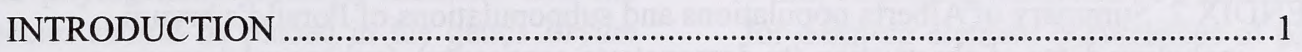

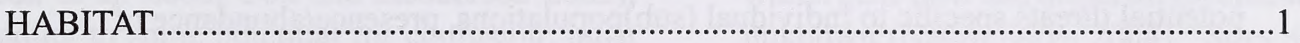

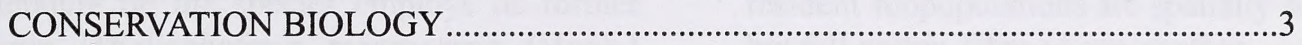

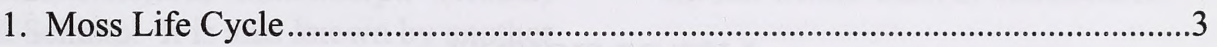

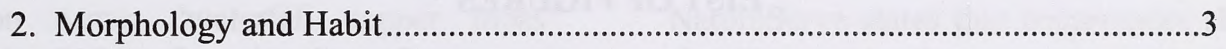

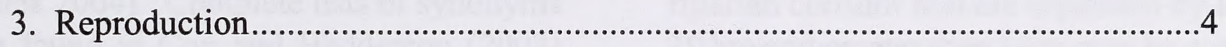

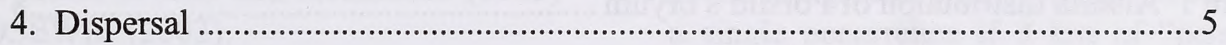

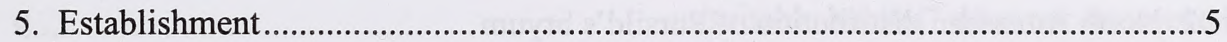

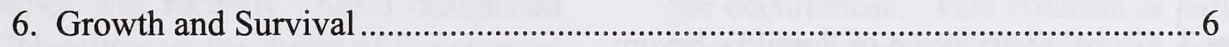

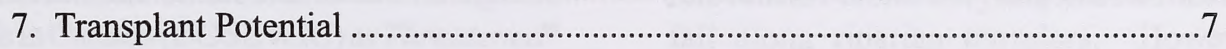

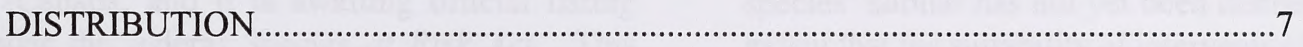

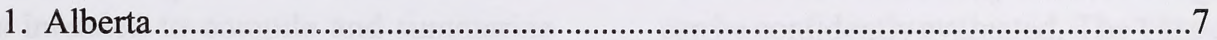

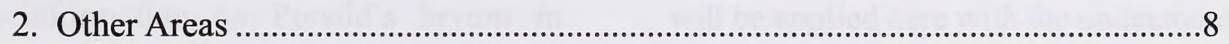

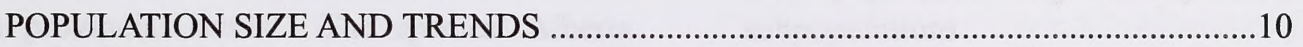

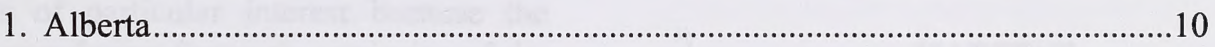

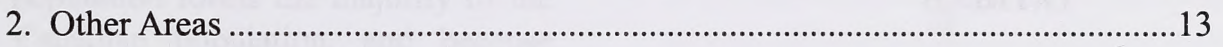

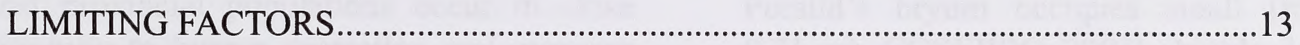

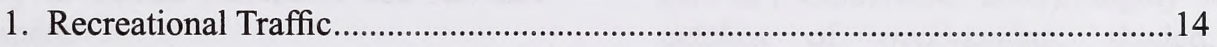

2. Natural Resource Development .........................................................................14

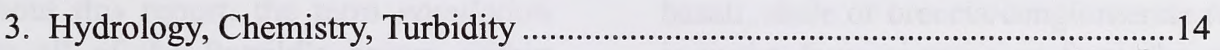

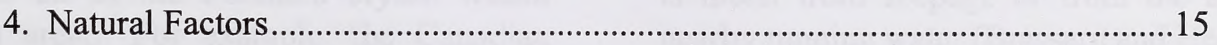

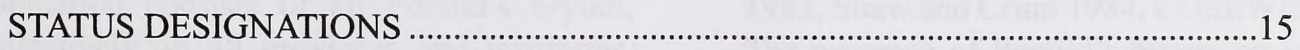

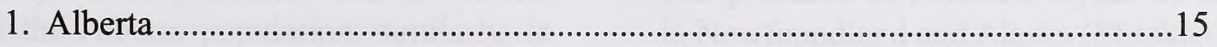

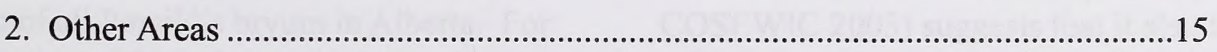

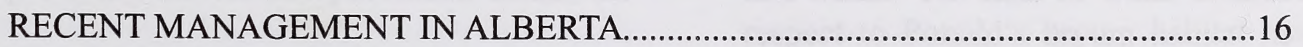


TABLE OF CONTENTS cont.

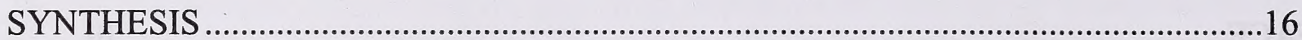

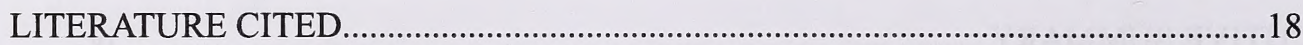

APPENDIX 1 Definitions of selected legal and protective designations .........................23

APPENDIX 2 Summary of Alberta populations and subpopulations of Porsild's bryum, including dates of observation (to demonstrate continuity), (sub)population sizes, potential threats specific to individual (sub)populations, presence/abundance of sporophytes, major associate species, and brief habitat descriptions

\section{LIST OF FIGURES}

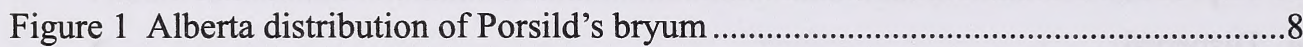

Figure 2 North American distribution of Porsild's bryum .................................................

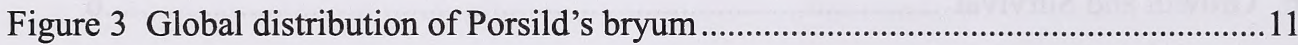




\section{INTRODUCTION}

Porsild's bryum (Bryum porsildii [I. Hagen] C. Cox \& Hedd.) is a small, brilliant green cushionforming moss that has been documented in widely disjunct locations around the northern hemisphere, including eight localities in montane and subalpine Alberta. Recent genetic and phylogenetic research indicates that the species should be placed in the genus Bryum (Cox et al. 2000, Cox and Hedderson 2003), leading to some potential for confusion: most literature on the species employs its former name, Mielichhoferia macrocarpa (Hook.) Bruch \& Schimp. It is also known by another common name: "waterfall copper moss" (Hortiplex 2004). Complete lists of synonyms may be found in Cox and Hedderson (2003) and COSEWIC (2003).

The species was recently (2003) designated by the Committee on the Status of Endangered Wildlife in Canada (COSEWIC) as Threatened* in Canada, and it is awaiting official listing under the federal Species at Risk Act. This report is intended to compile and summarize current information on Porsild's bryum in Alberta, as a basis for the determination of its provincial status. The species' Alberta status is of particular interest because the Alberta population forms the majority of the known Canadian population, and because most provincial populations occur in close proximity to human recreation and resource development.

Throughout this report, the term population refers to all of the Porsild's bryum within a given area. For example, the Canadian population consists of all Porsild's bryum, collectively, in all provinces and territories, whereas the Alberta population, similarly, is made up of all Porsild's bryum in Alberta. For populations on the sub-provincial scale, the

\footnotetext{
* See Appendix 1 for definitions of selected status designations.
}

term population is equated with, and will be used in place of, occurrence, as applied by the Alberta Natural Heritage Information Centre (ANHIC) and NatureServe.

In this report, therefore, localities and their resident populations (equivalent to occurrences) of Porsild's bryum are separated by at least $1 \mathrm{~km}$, reflecting NatureServe's default criteria for defining element occurrences of plants for which gene flow and dispersal specifications are unknown (NatureServe 2004). Sites and their resident subpopulations are spatially separated but fall within $1 \mathrm{~km}$ of one another.

NatureServe states that occurrences sharing a riparian corridor that are separated by less than $10 \mathrm{~km}$ and greater than $1 \mathrm{~km}$ may be considered a single occurrence if $3 \mathrm{~km}$ of "persistently unsuitable habitat" does not intervene between the occurrences. This criterion is particularly relevant to Porsild's bryum, since all occurrences fall along riparian corridors. However, the species' habitat has not yet been defined to the extent that the suitability of intervening habitats can be confidently evaluated. The $1 \mathrm{~km}$ criterion will be applied here with the understanding that some populations may one day be considered subpopulations.

\section{HABITAT}

Porsild's bryum occupies small (mean of $0.71 \mathrm{~m}^{2}$; COSEWIC 2003), highly localized patches of overhanging, shaded, often extensively dissected sandstone, limestone, basalt, shale or breccia/conglomerate rock that is moist from seepage or from the spray of nearby running water (Brassard and Hedderson 1983, Shaw and Crum 1984, COSEWIC 2003). The presence of Porsild's bryum on sea cliffs in Newfoundland and Alaska (Shacklette 1969, COSEWIC 2003) suggests that it also tolerates salt water. No tests of water chemistry with respect to Porsild's bryum habitat have been reported. Porsild's bryum has been collected mainly in montane habitats in Alberta and 
elsewhere, although it occurs near sea level in Newfoundland (considered to have a neararctic climate; R. Belland pers. comm.) and in the Arctic (Brassard and Hedderson 1983, COSEWIC 2003).

Although water bathes Porsild's bryum sites continually throughout the growing season, the species is not physiologically limited by drought intolerance. Water freezes at its Canadian (COSEWIC 2003) and Utah (Flowers 1973) sites during the winter, resulting in weeks or months of drought each year. There is speculation that this freeze-thaw cycle may be important physiologically and/or competitively for the species (COSEWIC 2003). Porsild's bryum has also been shown experimentally to be desiccation tolerant, with significantly greater fragment viability after four months' storage in air than in water (Cleavitt 2002a,b). Similarly, although Porsild's bryum occurs at shaded sites, the species grew well in a brightly lit growth chamber (Cleavitt 2002a,b), indicating that it is not physiologically limited to shady conditions.

Despite Cleavitt's (2001; 2002a,b) extensive observations and experiments, the absence of Porsild's bryum from some apparently suitable wet, rocky sites (Cleavitt 2002a) confirms that additional unknown factors relating to dispersal, establishment or habitat may govern its distribution and abundance. Provincially rare and uncommon moss species, such as Hygrohypnum smithii, Timmia norvegica, Cirriphyllum cirrosum and Encalypta vulgaris, grow with Porsild's bryum at some sites (Appendix 2), suggesting that rare or uncommon growing conditions may exist at these locations. However, no single bryophyte species is a major associate of Porsild's bryum at all Alberta sites.

One habitat characteristic that needs further research is substrate chemistry. Alberta sites for Porsild's bryum feature calcareous substrates (COSEWIC 2003), and some evidence suggests that the species may be a calciphile; when fragments of the species were experimentally transplanted to acidic, organic substrates they displayed poor regeneration compared with fragments grown on native calcareous conglomerate (Cleavitt 2001, 2002a). Fully crossed experiments (including acidic mineral and calcareous organic substrates) and analysis of the water that bathes the sites would be required to confirm this preference. Most species co-occurring with Porsild's bryum in Alberta, such as Hymenostelium recurvirostre, Cratoneuron filicinum and Ditrichum flexicaule (Appendix 2), are described as calciphilic (Lawton 1971, Crum and Anderson 1981). Conversely, Shaw and Crum (1984) state that Porsild's bryum often occurs on extremely acidic substrates, presumably outside its Alberta range.

Porsild's bryum is known as a "copper moss," along with northern species of the genus Mielichhoferia (e.g., Brassard 1969; Brooks 1971; Persson 1956; Shacklette 1967, 1969; Shaw and Crum 1984; Shaw 1994), to which Porsild's bryum was thought to belong until recently (Cox and Hedderson 2003). Some moss species are well-known indicators of mineral relationships in the substrates on which they occur (e.g., Brown 1982), and Shacklette (1967) suggested that the Mielichhoferia were so closely and consistently associated with greater-than-average concentrations of heavy metals at his Alaska research sites that they should be used as indicators of "useful deposits of minerals." However, no formal experimental or observational work has been conducted, either in Alberta or elsewhere, to confirm the existence of a relationship between the occurrence of Porsild's bryum and concentrations of a mineral in its habitat (Brassard and Hedderson 1983, Shaw and Crum 1984, COSEWIC 2003). N. Cleavitt (pers. comm.) argues, furthermore, that the removal of Porsild's bryum from Mielichhoferia removes the basis for assuming that the species is indicative of heavy metals. 
However, a pattern among Alberta and Nunavut populations of Porsild's bryum suggests that the issue of heavy metals should not be dismissed outright. The Michigan site for Porsild's bryum occurs in a region with a long history of copper mining (e.g., Roberts 1996). All Alberta sites are in or near current or historical coal mining areas, and coal deposits were observed at Ellesmere Island sites for Porsild's bryum, where the species grew in close proximity to another copper moss, Mielichhoferia elongata (J. Doubt pers. obs.). Brassard (1969) found higher than average amounts of copper, boron and lead below a sample of $M$. elongata collected a few kilometres from a Porsild's bryum site in Nunavut, and suggests that Porsild's bryum may have been associated with the same deposit. Although the presence of heavy metals in a localized substrate does not follow directly from the presence of coal or mineral deposits in a region, the informal correlation merits investigation. Webster (1985) reported elevated heavy metals in the moss Pohlia nutans growing in seepage issuing from a coal seam exposed 20 years previously in a sandstone road cut in Pennsylvania. Systematic analysis of Porsild's bryum substrates and plants, and experimental toxicity studies, would help to determine whether or not heavy metals play a role in limiting the species' distribution or abundance (COSEWIC 2003).

Changes to any aspect of the habitat of Porsild's bryum, whether or not a physiological link has yet been demonstrated, have the potential to affect habitat quality. For example, the construction of a gravel haul road with projected frequent, long-term traffic adjacent to one Porsild's bryum population recently prompted COSEWIC (2003) to conclude that the habitat quality of at least one Alberta site had declined. However, the habitats with which Porsild's bryum is associated are not known to be generally declining in number in the species' Canadian or global ranges. Details of existing and potential population decline related to habitat change are discussed in the Limiting Factors section of this report.

\section{CONSERVATION BIOLOGY}

1. Moss Life Cycle. - The moss life cycle has four main stages-reproduction, dispersal, establishment and growth - that are functionally similar to those seen in vascular plants, but which are accomplished by means unique to bryophytes.

Mosses such as Porsild's bryum reproduce sexually (the species is dioicous, which denotes that there are separate male and female plants) to produce short-lived (usually several months) spore-bearing structures known as sporophytes that are attached to and dependent on the longlived (usually many generations) and more familiar leafy green gametophytes. Spores are released from capsules at the tops of the sporophytes and are dispersed through the air or water.

Upon contact with a favourable substrate in a suitable microhabitat, these spores germinate to produce delicate, unspecialized green filaments known as protonemata. Gametophytes grow from the protonemata and possess specialized features, including those that botanists use to identify the plants, that allow them to exploit their preferred habitat. For Porsild's bryum, each gametophyte, consisting of the stem or stems (and their associated branches, leaves and reproductive structures) generated from a single attachment point, is considered an individual plant. Gametophytes proliferate vegetatively to form colonies composed of genetically identical plants, offering additional protection to each individual. Mosses occupying discrete habitats such as rock outcrops have limited space in which to expand before dispersal (by means of sexual or asexual propagules) over longer distances becomes necessary.

2. Morphology and Habit - The following description constitutes a summary of more detailed accounts in Shaw and Crum (1984) and COSEWIC (2003). Illustrations may be found in Shacklette (1967), Lawton (1971), Flowers (1973), and Shaw and Crum (1984). 
Porsild's bryum grows in cushion- or turf-style colonies of closely arranged plants ranging from $0.3 \mathrm{~cm}$ to $1 \mathrm{~cm}$ tall. Cushions, when they are (as they are typically) saturated with water from seepage or splash, have a spongy texture and characteristic brilliant green colour. A shiny or sparkly aspect, visible on close observation with a hand lens, arises from the species' relatively large, lax (loose, thinwalled), unornamented leaf cells.

Stems and branches are green at their tips and red-brown in their lower portions, where they are also covered by dense rhizoids (rootlike structures appearing as brown fuzz). Upper, younger leaves are green, somewhat concave, and wide-spreading to recurved (bent backward). Lower leaves, which are obscured from view in intact colonies, may be white.

Male and female plants are morphologically distinct; the male plants are generally smaller with the leaves more crowded to form a leaf rosette. Sporophytes may be generated, at times copiously, from the tips of female gametophytes (one sporophyte per gametophyte shoot or stem per reproductive cycle). Sporophytes, each consisting of a short $(4-11 \mathrm{~mm})$, curved stalk (seta) and an ovoid capsule terminating the seta just beyond the leaves, are light beige or brown. The tip of each capsule is capped by an operculum (lid) that falls off at maturity, opening a narrow mouth (stoma) surrounded by projections known collectively as a peristome, through which spores (13-23 $\mu \mathrm{m})$ are released.

Whereas the so-called "perfect peristome" in bryophytes consists of inner and outer layers of well-developed peristome teeth that regulate spore dispersal, the peristome of Porsild's bryum consists of a single layer of 16 irregular, delicate, hyaline (transparent) to whitish, blunt teeth. This reduced peristome in Porsild's bryum, which is now thought to have originated separately (evolutionarily speaking) from the morphologically similar peristome characteristic of the genus Mielichhoferia, helps to explain the species' former generic assignment.

The appearance of dry colonies differs significantly from that of moist ones. Leaves fold and contort and appear a light, dull green. This appearance is rarely observed, but is important to recognize in case of local or regional drought conditions. The majority of plants discovered at Whitehorse Falls in 2004, for example, were dry.

\section{Reproduction. -}

Sexual reproduction: As Porsild's bryum is dioicous, sperm must swim from the antheridia of male plants, through the water saturating the colonies, to reach eggs in the archegonia of female plants. The plants within a single colony tend to represent a single gender (since colonial expansion results from clonal growth), necessitating transfer of sperm between colonies. The maximum effective range of motile moss sperm is estimated to be $10 \mathrm{~cm}$ (e.g., Longton 1976, Rohrer 1982); however, this may be extended in species such as Porsild's bryum by the gravitational flow or splashing of water that are characteristic of the species' preferred habitat.

Although dioicous moss species are generally thought to be at a reproductive disadvantage compared to autoicous mosses (in which sperm need only swim between antheridia and archegonia on the same plant) (e.g., Longton 1976), Porsild's bryum produces sporophytes frequently. Cleavitt (2002a) reported that sporophytes occurred on $10.7 \%$ of colonies, based on a census of 50 colonies at each of three sites. Brassard and Hedderson (1983) also report that most Porsild's bryum populations produce sporophytes. Sporophytes were recorded in seven of the 12 extant Alberta subpopulations examined for this report (Appendix 2), and COSEWIC (2003) reported that they were recently present (2002) at the one site that could not be closely examined for this report in 2004 . Nonetheless, small (sub)populations are less 
likely to support both sexes, and sporophytes have not been observed in Alberta's smallest subpopulations (Appendix 2). Maintaining populations of sufficient size may therefore be important to conserving the species. Porsild's bryum is difficult to classify in terms of generation time (which has not been studied). The species' morphology and spore size may indicate that it employs a "colonist" life strategy (During 1992), characterized by relatively short life span and prolific spore production. Succession on the disturbed (vertical, unstable, water- and frost-scoured) substrates preferred by Porsild's bryum is generally prevented by repeated disturbance, perhaps allowing for the anomalous long-term persistence of a colonist species over time.

It should be noted that mosses, in microclimates that are changing or have recently changed (e.g., flood, drought, canopy clearing), are often observed to produce sporophytes profusely (COSEWIC 2003, J. Doubt pers. obs.). Although the phenomenon is not well documented, it is possible that in cases of prolonged physiological stress, mosses may allocate more resources to sporophyte production to increase chances of dispersal success. Shifts in the number of sporophytes should be monitored along with shifts in colony number or size and habitat parameters to provide the most complete information possible regarding population status.

Asexual reproduction: In addition to asexual reproduction by colony expansion, which is characteristic of colonies that have not fully exploited the extent of locally favourable growing conditions, vegetative fragments of Porsild's bryum may function as asexual diaspores. Fragment viability experiments in laboratory settings suggest that Porsild's bryum can regenerate from plant fragments that break off of existing plants and disperse to new sites (Cleavitt 2001; 2002a,b). In most experimental cases, filamentous protonemata resembling algal filaments grew from the stem of a detached fragment, which in turn generated the more familiar leafy plants. However, direct sprouting of leafy plants from plant fragments was also observed. The existence of a genetically homogeneous subpopulation (consisting of several colonies) was interpreted by COSEWIC (2003) as evidence that asexual reproduction occurs naturally in the field. However, in addition to short-range dispersal of asexual propagules, this situation could also arise from the fragmentation of a large continuous colony.

4. Dispersal. - The primary modes of dispersal in Porsild's bryum are unknown. On one hand, the riparian distribution of Porsild's bryum situates it well for dispersal of spores or fragments by water. In Alberta, the presence of Porsild's bryum at several stations along Whitehorse Creek and at least two stations along Ribbon Creek is consistent with water-mediated dispersal. On the other hand, the species' high viability after dry storage (Cleavitt 2002a,b) makes air-mediated dispersal plausible as well, and the presence of the species upstream of Whitehorse Creek on two separate tributaries suggests dispersal through air.

The effective dispersal distance of Porsild's bryum spores is unknown. Although most moss spores are known to fall close to their parent plants (e.g., Longton 1976), the high number of spores per bryophyte capsule and the small size of bryophyte spores make mosses theoretically better-suited to longrange dispersal than are vascular plants. The distribution patterns (Shaw 1994, Shaw and Schneider 1995) and biological characteristics of Porsild's bryum give sufficient evidence for and against successful long-range dispersal to fuel lively debate in the bryological community (references in Shaw 2001).

5. Establishment - COSEWIC (2003) emphasizes that successful dispersal and establishment of Porsild's bryum (by either sexual or asexual propagules) are very rare. In 
three experiments in which the regeneration of plant fragments in the field and in the growth chamber was measured, regeneration success varied widely, presumably in response to differences in growth conditions and length of experiments (Cleavitt 2002a). Successful regeneration from fragments in the field was only $25 \%$ after one year, while immediately after harvest almost all fragments planted on agar and grown in a growth chamber showed regeneration. Similarly, Cleavitt (2002a) demonstrated relatively high spore viability, reporting $55.7 \% \pm 4.1 \%$ germination on agar. However, spore germination on natural rock substrate did not occur under experimental conditions, suggesting that unknown factors limit the success of plant establishment from successfully dispersed spores. Preservation of existing habitats is therefore critical to the species' survival (COSEWIC 2003).

\section{Growth and Survival. - The habitats} preferred by Porsild's bryum are quite unstable and are subject to frequent natural disturbance and change. Water saturating and permeating the vertical and overhanging rock on which Alberta populations grow promotes the weakening, cracking, flaking and breaking off of the characteristically unstable soft shale or conglomerate substrate. Freeze-thaw cycles accelerate the disturbance. Fine silt, characteristic of cliff crevices and ledges, slides frequently when wet. One season of particularly intense frost action recently reduced what was Newfoundland's (and Canada's) largest population from hundreds of colonies to just nine (COSEWIC 2003), demonstrating the dynamic nature of Porsild's bryum population size. From 1997 to 2000, three Alberta subpopulations showed growth in an average of $52.9 \%( \pm 6.15 \%)$ of colonies. Reduction or death was seen in $18.8 \%( \pm 8.01 \%)$ of colonies, and $14.7 \%( \pm 4.41 \%)$ disappeared from the monitored area. The remaining minority $(13.6 \% \pm 8.82 \%)$ did not change in size, and several new colonies were initiated (COSEWIC 2003).
Seasons of drought may result in population decline, as suggested when populations carefully monitored for three years, ending in 2000 , were re-visited for the COSEWIC national status report in 2002 (COSEWIC 2003). On the other hand, laboratory experiments have shown that Porsild's bryum demonstrates resilience under short-term experimental drought conditions. Physiological activity, as indicated by the activity of photosynthetic pathways, was shown by Cleavitt $(2002 a, b)$ to recover within $24 \mathrm{~h}$ of a three-day experimental drought. Recovery was greatest when colonies - as opposed to individual plants-were dried, and indeed, the survival of winter drought (caused when the water that normally flows or seeps over their substrates freezes) is a normal part of the colonies' annual cycle in the field. In desiccation-tolerance experiments, dried fragments of Porsild's bryum consistently germinated on agar after four months' storage (Cleavitt 2002a,b). Despite these experimental results, longer-term growing-season drought, as might be expected at Alberta field sites in coming years due to global climate change, may overcome the species' drought tolerance (COSEWIC 2003). Predicted earlier peak run-off times (Stewart et al. 2004, references cited in Rood et al. 2005) and declining stream flow (Rood et al. 2005), in combination with predicted temperature increases (Luckman and Kavanagh 2000, Stewart et al. 2004), all have the potential to significantly affect Porsild's bryum habitat.

Few instances of other species overgrowing Porsild's bryum have been recorded, which may suggest that the role of competition in limiting the species is small (Cleavitt 2002a). Competition for resources (water, nutrients, light) is most likely to come from neighbouring bryophytes, because the vertical or overhanging substrates preferred by Porsild's bryum are not conducive to the growth of most vascular plants (COSEWIC 2003) (note, however, that ferns have been observed at some sites; J. Doubt pers. obs.). However, sites where Porsild's 
bryum occurs do tend to have a lower percent cover of other bryophyte species and a higher percentage of bare rock than apparently suitable sites where the species is not found, which may be interpreted as evidence for competitive exclusion (COSEWIC 2003).

That no instances of natural extirpation have been reported suggests that such events are uncommon, despite often-dramatic fluctuations resulting from factors such as natural physical disturbance and drought. Long-term persistence of Alberta subpopulations is demonstrated in Whitehorse Creek Provincial Recreation Area, where the "boulder" site has been documented for almost 40 years (Appendix 2). Some North American populations have been known to persist for extremely long periods of time: Greenland's Disko Island population was recorded periodically from 1898 to 1977 (Brassard and Hedderson 1983).

\section{Transplant Potential. - Low experimental} transplant success (Cleavitt 2002a) suggests that Porsild's bryum is a poor candidate for transplant in recovery efforts. The wet, vertical or undercut, unstable substrates preferred by the species, which are often washed by flowing water, make artificial attachment difficult. Furthermore, as noted in preceding sections, habitat requirements (such as temperature, light, water and substrate chemistry) are not fully understood. As a result of low transplant viability, logistical impediments, and our inability to predict where viable transplants might succeed, transplantation is not a plausible recovery strategy.

\section{DISTRIBUTION}

1. Alberta. - Porsild's bryum was first described from material collected by Thomas Drummond, an early explorer and botanist, in presentday Jasper National Park, Alberta, in 1828. This population, described as occurring at the junction of the Snake Indian and Athabasca rivers (Bird 1967, 1968), has never been pinpointed by contemporary botanists (e.g., D. Vitt, R. Belland and N. Cleavitt pers. comm.), making the current status of the population impossible to determine. No other records of Porsild's bryum are reported from Jasper, although N. Cleavitt (pers. comm.) suspects that inaccessible colonies may occur at Athabasca Falls.

Following Drummond's report, Porsild's bryum was not documented again in Alberta until 1966. The population documented in 1966 and all subsequently recorded Alberta populations are extant at the time of this report, and some North American populations of Porsild's bryum have persisted for long periods (Brassard and Hedderson 1983), suggesting that the species' Alberta distribution may be somewhat stable over time. No populations are known to have been extirpated.

All Alberta populations of Porsild's bryum have been recorded in the province's Rocky Mountain Natural Region, within the Montane and Subalpine subregions, where they occur in three general areas separated by about $450 \mathrm{~km}$ or less: 1) along Ribbon Creek in Evan-Thomas Provincial Recreation Area (Kananaskis Country), 2) along the Whitehorse Creek and some of its tributaries in Whitehorse Creek Provincial Recreation Area / Whitehorse Wildland Park, and south of Whitehorse Creek in nearby Mountain Park / Cardinal Divide, and 3) on Casket Creek and an unnamed stream in Willmore Wilderness Park (Figure 1). Although 12 spatially separated subpopulations have been found to date, there is not sufficient separation (default of at least $1 \mathrm{~km}$ in the absence of detailed data on population biology and dispersal) to classify each as a separate occurrence or population according to the methodology applied by the Alberta Natural Heritage Information Centre (ANHIC). When ANHIC methodology is applied, there is one population (composed of two subpopulations separated by about $445 \mathrm{~m}$ ) in Kananaskis, four populations (each composed of one to four 


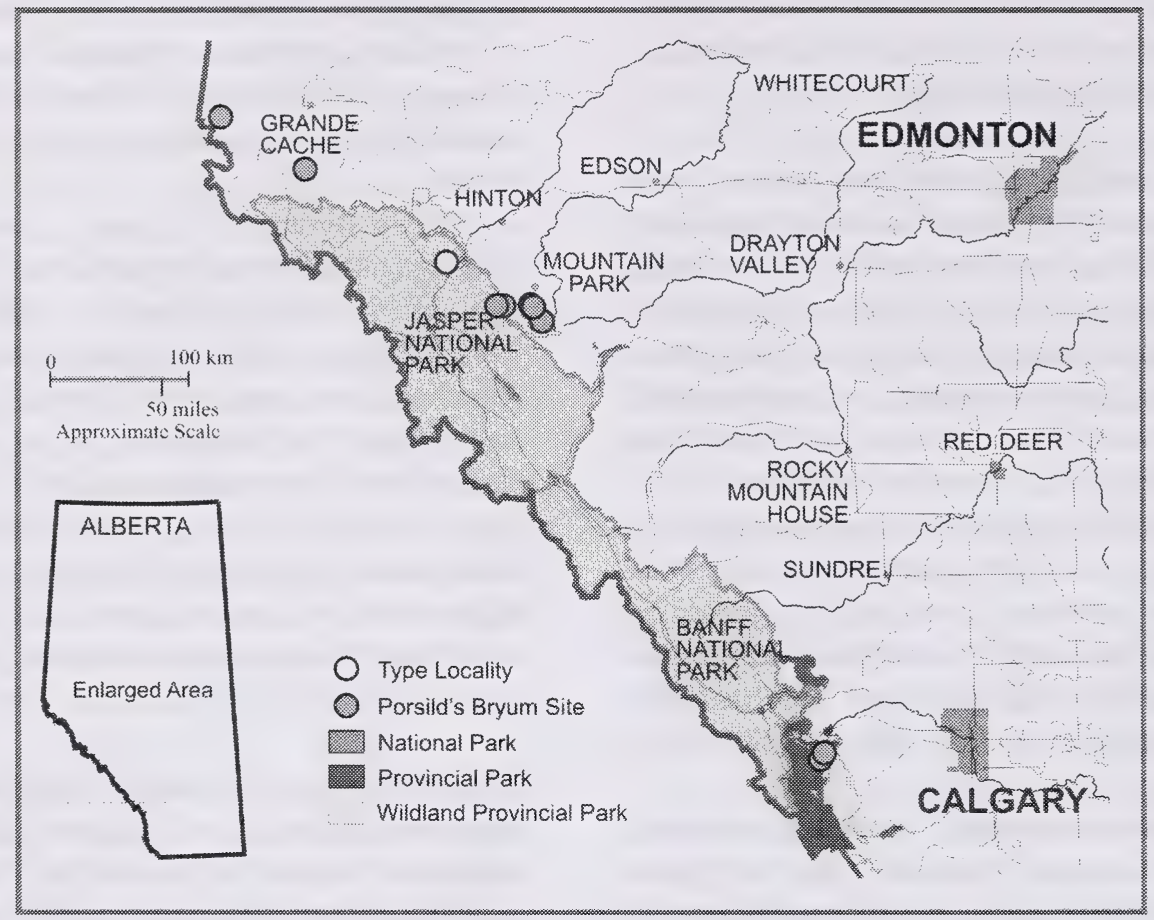

Figure 1. Alberta distribution of Porsild's bryum.

spatially separated subpopulations) within a total area of about $35 \mathrm{~km}^{2}$ on and near Whitehorse Creek, and two populations (separated by about $50 \mathrm{~km}$ ) in Willmore Wilderness Park.

\section{Other Areas. -}

National: Porsild's bryum also occurs in northern British Columbia (about $650 \mathrm{~km}$ from the nearest Alberta population), Nunavut and Newfoundland (Figure 2). Alberta's populations, occupying a combined total of at least $37 \mathrm{~m}^{2}$ (population sizes in Willmore Wilderness have not been evaluated and are not included in this total), are estimated to be larger in terms of their combined areal extent than those in British Columbia (less than $1 \mathrm{~m}^{2}$ ) or in Newfoundland (18 $\mathrm{m}^{2}$; COSEWIC 2003).
Bryophytes are under-studied in the majority of Canada's Arctic. Recent surveys in Ellesmere Island (J. Doubt pers. obs.) documented populations totalling at least $5 \mathrm{~m}^{2}$ (pending examination of specimens and data), and evidence of historical Arctic records (Andrews 1932, Brassard 1971, Brassard and Hedderson 1983; Figure 2) indicate that additional Arctic populations may be documented if sought.

The rarity of Porsild's bryum differs in significant ways from that of other nationally rare species. Canadian populations of many nationally rare species represent peripheral segments of larger populations centred outside the country. That is, the distributional ranges of some common species in the United States reach 


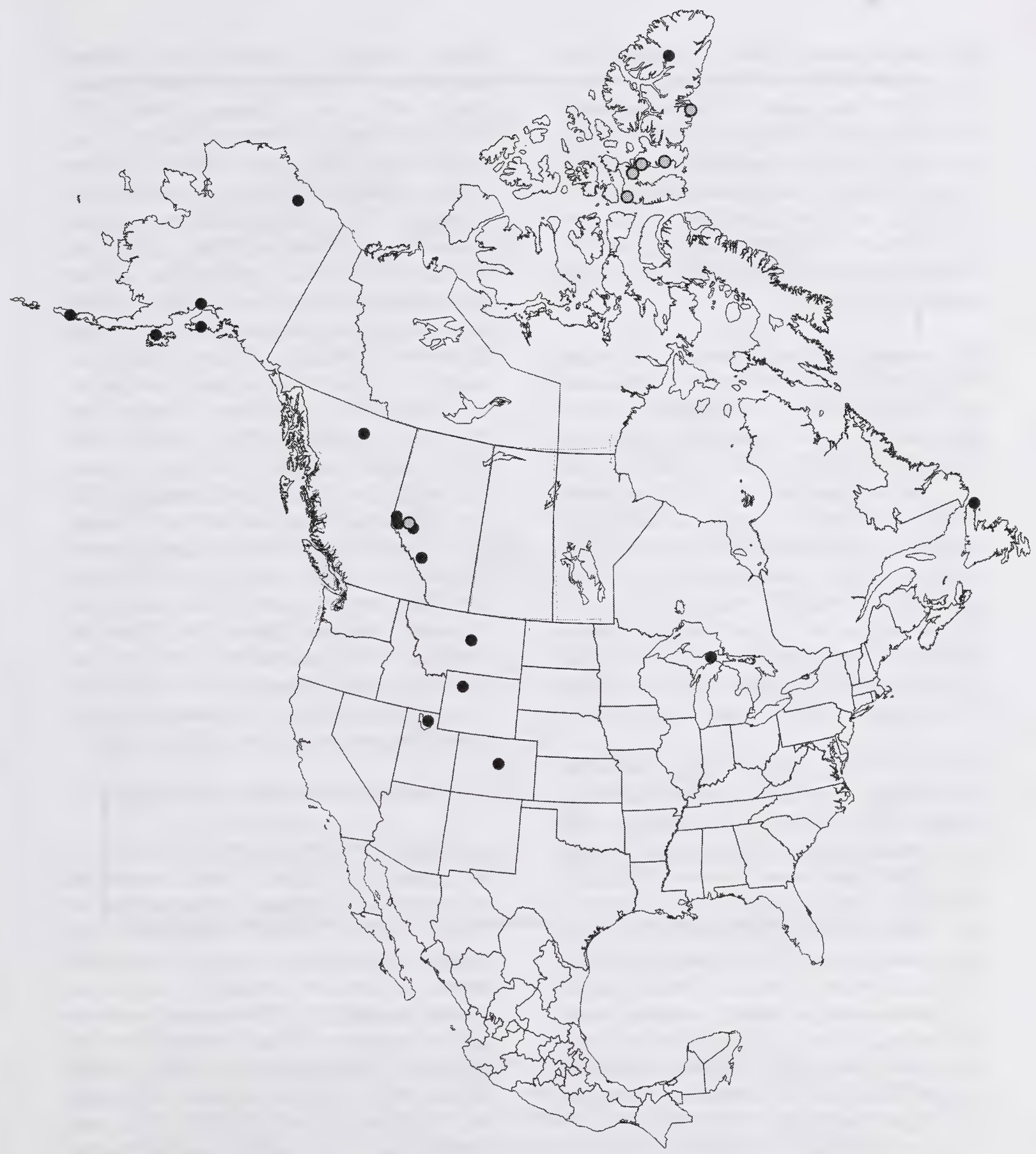

Figure 2. North American distribution of Porsild's bryum, adapted from COSEWIC (2003) with additions from Andrews (1932), Brassard (1971), Brassard and Hedderson (1983) and Missouri Botanical Garden (2004). Grey circles represent occurrences documented in the 1800 s, for which no specimen has been verified by a contemporary bryologist. Although COSEWIC (2003) excluded Colorado from the distribution on the basis of two misidentified herbarium specimens, the Colorado Natural Heritage Program (2004) lists the species as S2, indicating that over five occurrences are known for the state. 
their northern-most limits in Canada, where they become rare. Porsild's bryum, however, does not fit this pattern. Canada supports a larger proportion of the global Porsild's bryum population than any other nation, and Alberta in turn supports the greatest proportion of Canada's population. Its peripheral populations are elsewhere. Preservation of the species in Alberta is critical to preserving the national and global populations.

International: Although Porsild's bryum was thought to be endemic to North America until the 1980s (Brassard and Hedderson 1983), its distribution is now described as "Holarctic disjunct" (COSEWIC 2003) because it has since been documented in widely separated localities across the northern hemisphere. According to Schofield and Crum (1972), the small, localized populations and high habitat specificity of Porsild's bryum are typical of disjunct bryophyte species. Its global rarity and disjunction, furthermore, are characteristic of other so-called "copper mosses" (Persson 1956, Brooks 1971, Shaw and Crum 1984).

Porsild's bryum is known from Canada, the United States, Greenland, southern Siberia, the southern Ural Mountains in Kazakhstan, and the Sayan Mountains of central Asia (Shaw and Crum 1984, Ignatov and Afonina 1992, Shaw and Rooks 1994, COSEWIC 2003; Figures 2, $3)$. Alaska possesses the majority of known populations in the United States (COSEWIC 2003). Elsewhere in the U.S, Porsild's bryum has been recorded in western montane regions of Montana, Colorado, Utah (Shaw and Crum 1984) and Wyoming (Missouri Botanical Garden 2004), and further east on Michigan's Keweenaw Peninsula (COSEWIC 2003) - a region well-known for disjunct records of arctic and montane plant species (e.g., Wells and Thompson 1974, Marquis and Voss 1981) and calciphilic bryophytes (Glime and Slavick 1985). The U.S. occurrence of Porsild's bryum that is nearest to Alberta lies in Montana, about $760 \mathrm{~km}$ from the southernmost Alberta occurrence of the species.
Some attempts to explain the disjunct distribution of Porsild's bryum have invoked glacial refugia (e.g., Brassard 1969, 1971; Steere 1978; Belland 1987) and long-distance dispersal (e.g., Shaw 1994). Indeed, evidence for the existence of a plant refugium in the Mountain Park / Cardinal Divide area has been debated (e.g., Packer and Vitt 1974, Strong 1999), and consensus suggests that northern and montane disjunct bryophytes in the Great Lakes-St. Lawrence region (where the Michigan occurrence of Porsild's bryum is found) are relicts of a more widespread distribution, remaining after glacial retreat (Marquis and Voss 1981, Belland 1987). However, the high ecological specificity of copper mosses (including Porsild's bryum) suggests that they may never have had continuous ranges (Shacklette 1967), and that long-range dispersal (possibly very rare instances over the very long term) may be responsible for their highly disjunct distributions (Shaw 1994, Shaw and Schneider 1995), despite the apparently low rate of successful dispersal and establishment in Porsild's bryum (see Reproduction section under Conservation Biology in this report).

\section{POPULATION SIZE AND TRENDS}

1. Alberta. - For this report, the locations of all known (as of 2004) Alberta populations (including each component subpopulation) of Porsild's bryum, except Drummond's 1828 Jasper site (which has not been found despite several attempts over the past 30 years), were visited (Appendix 2). Within one to two hours per site, the extent of each subpopulation was estimated, photographs were taken, major associate species were collected, the habitat was characterized, and potential threats were investigated. By examining suitable habitat near three sites, two new subpopulations were documented in the same manner. One exception, a known site along Whitehorse Creek, could not be examined closely because the subpopulation occurs on a sheer cliff above a deep pool in a fast section of the creek. N. Cleavitt (pers. comm.) 


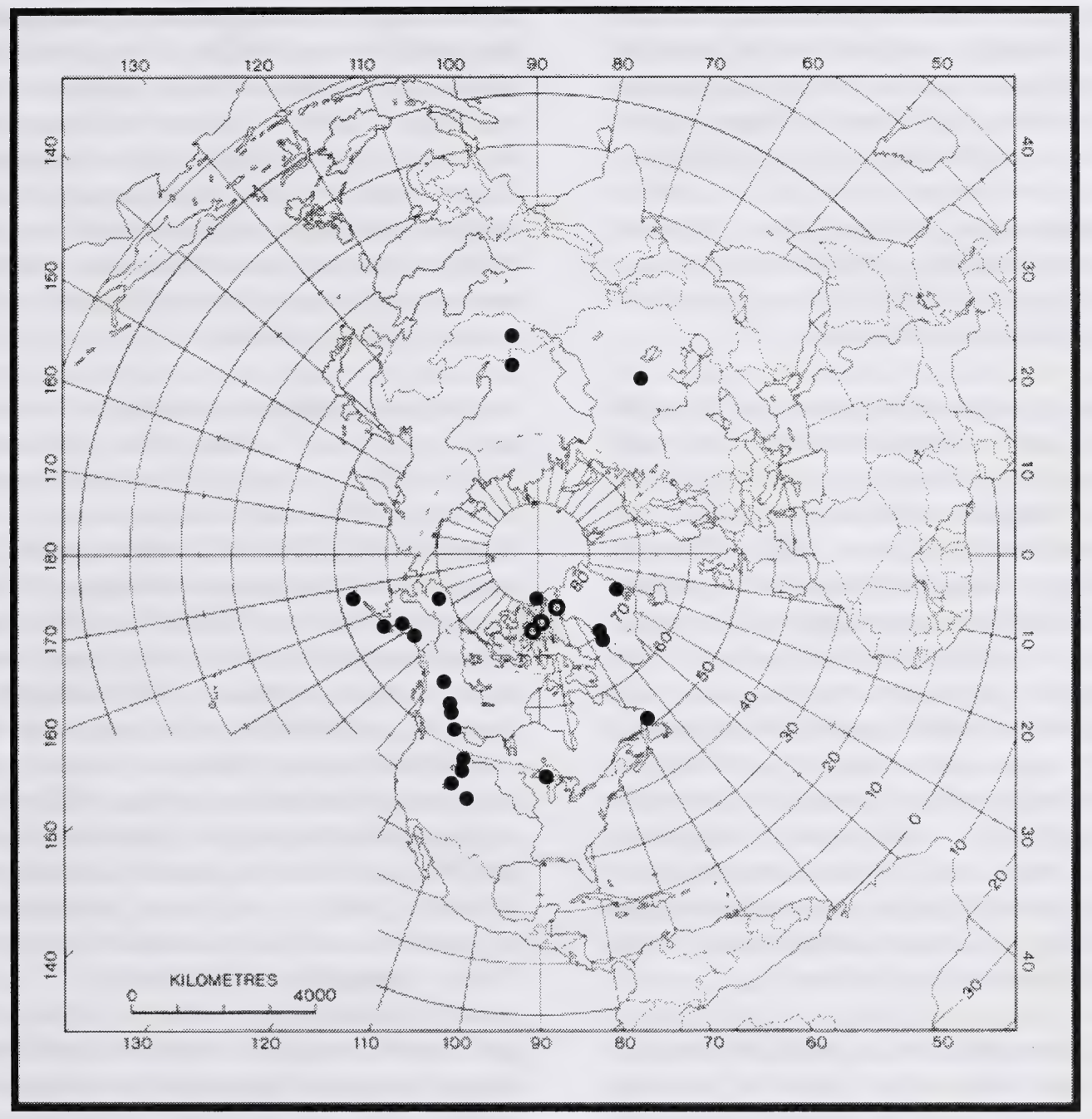

Figure 3. Global distribution of Porsild's bryum, adapted from COSEWIC 2003 with additions from Andrews (1932), Brassard (1971), Brassard and Hedderson (1983) and Missouri Botanical Garden (2004). Open circles represent Canadian Arctic occurrences documented in the 1800 s, for which no specimen has been verified by a contemporary bryologist. 
assessed this subpopulation in early spring before the creek was at full flow. By observing the site through binoculars from the far side of the creek in 2004 it was possible to determine that no evidence of recent disturbance existed and that colonies and habitat typical of other occurrences persisted at the site, but detailed assessment was not possible. Willmore Wilderness populations were discovered during the review period of this report, and population sizes have not been evaluated.

Known Alberta subpopulations of Porsild's bryum have persisted over time (up to 38 years), which appears to be characteristic of occurrences outside the province as well (Brassard and Hedderson 1983). However, trends in the size of individual subpopulations are difficult to assess, owing to differences in the methods employed by various observers through time, and to what may be a fairly wide amplitude (potentially greater than one order of magnitude, as demonstrated by Newfoundland populations) in natural population fluctuation in response to local, natural disturbance (see Growth and Survival section under Conservation Biology). As a result, any trend in the size of the Alberta population as a whole cannot be assessed at this time.

Bryophytes are often so small and occur in such large numbers that counts of individual plants are generally not practical (Hallingbäck et al. 1998). Assessment of population size in bryophytes generally involves some estimate of colony numbers and/or the area occupied. By supplying and clearly defining both values, one can help to compensate for uncertainty associated with colony counts alone. For example, when adjacent colonies expand to the point where they touch, should they be counted as a single colony? If so, how does one demonstrate population growth if the number of colonies is decreasing? COSEWIC (2003) reported colony number and area occupied for Porsild's bryum, but did not clearly define either measure, making later observations difficult to interpret in terms of trend over time. In an attempt to gather data on population size that could be compared to those recorded by COSEWIC (2003), colonies (discrete units, regardless of size and shape) were counted for this report as well. Colony area was measured if there were very few colonies present. At sites with many colonies, the area within which colonies occurred was estimated (including area covered by moss and area that was bare or covered by other species).

In 2004, subpopulations varied in size from two small colonies at Lookout Falls, Whitehorse Wildland Park, to over 100 colonies at two sites along Whitehorse Creek and at one site in Mountain Park / Cardinal Divide (Appendix 2). Large differences between the subpopulation sizes recorded by COSEWIC (2003) and those recorded for the current report were apparent at some sites (e.g., Whitehorse Creek 4 and $4 \mathrm{a}$, and Boulder sites-see Appendix 2). Whether these differences resulted from changes in subpopulation size or differences in measurement techniques is not clear. In the absence of evidence of obvious disturbance, it seems possible that some measurement inconsistencies existed. In thecase of Whitehorse Creek subpopulations 4 and $4 \mathrm{a}$, it is also possible that the subpopulation identifiers were inadvertently reversed in some existing reports, so that the true Whitehorse Creek 4 became known as $4 \mathrm{a}$ and vice versa. Photographs and GPS technology should alleviate this uncertainty on future visits. Future observers should carefully detail measurement methods for population size (number of colonies, area occupied), and should also consider reporting density of occurrence, either in terms of percent cover within the area where the species occurs or using mean/maximum/minimum colony size as an additional indicator of abundance.

For subpopulations at sites where population size values were comparable between COSEWIC (2003) and the current report, 2004 values tended to be lower than previous 
measurements (Appendix 2). COSEWIC (2003) attributes the decrease in the size of some subpopulations (which are not specified) to drought in the Whitehorse Creek area between 2000 and 2002, which may have persisted through to the time of this report. In 2004, unhealthy (dry and/or brown) colonies were observed at Whitehorse Creek Boulder and Whitehorse Falls 2 sites (Appendix 2). Cleavitt's (2002a) detailed monitoring of three subpopulations in or near Whitehorse Wildland Park documented a mean colony size of $22 \mathrm{~cm}^{2}$ (s.d. $27 \mathrm{~cm}^{2}$ ), a mean area required to encounter 50 colonies of $0.71 \mathrm{~m}^{2}\left(+/-0.31 \mathrm{~m}^{2}\right)$ and a mean percent site cover of $15 \%$.

2. Other Areas. - Canadian populations of Porsild's bryum outside Alberta (those that have been measured) tend to be smaller than Alberta populations. Trends have not been measured, although one Newfoundland population, once the largest single occurrence in Canada in terms of number of colonies and area covered at a site, was recently reduced to nine colonies in a single season of exceptional frost disturbance. Populations in Nunavut have not been fully assessed.

\section{LIMITING FACTORS}

COSEWIC (2003) expressed concern that of all known Canadian populations, those in Alberta and British Columbia are at the greatest risk from human activity. Unlike British Columbia and Newfoundland populations of Porsild's bryum, which occur on public land with no protective designation, all but one of the known Alberta populations occur within the boundaries of provincial parks, where they are protected, to some degree, from urban and industrial development. These protected areas have different intents. In wildland parks such as Whitehorse Wildland, the primary intent is to preserve and protect natural heritage and to provide opportunities for backcountry recreation whereas recreation areas such as Evan-Thomas and Whitehorse
Creek support outdoor recreation and tourism (Alberta Community Development 2005). Willmore Wilderness Park is governed by its own legislation but its conservation objectives are similar to those of wildland parks (Alberta Community Development 2005).

Despite their protection, most Alberta populations, in whole or in part, lie in areas with high levels of recreational or resource development traffic. Futhermore, in Mountain Park / Cardinal Divide, Porsild's bryum occurs on public land with no protective designation. Since 1974, the area has been recommended for protection by several governmental and nongovernmental organizations citing, for example, the area's high concentration of rare species and biodiversity, its environmental, geographical and geological significance, and its ecological interdependence with the adjacent Canadian Rocky Mountains World Heritage Site (e.g., Sierra Club of Canada 2004, Nature Canada 2005, Alberta Wilderness Association 2006). Competing interests of resource development, recreation, and conservation have made the area the subject of considerable controversy. In contrast with Alberta populations, at least one of the other Canadian populations of Porsild's bryum occurs in an area where visitors (and, therefore, direct human impacts) are few: on Ellesmere Island, within Qittinirpaq National Park.

Anthropogenic factors with the greatest potential to affect the abundance and distribution of Porsild's bryum vary among the locations where the species occurs. At some sites (including the unprotected Mountain Park / Cardinal Divide site), the moss comes into close, direct contact with recreational traffic and natural resource development activity. The species' dependence on a narrow subset of stream/seepage habitats also makes it particularly vulnerable to changes in hydrology, chemistry or turbidity. Natural limitations such as habitat and substrate specificity, potential dispersal difficulties and low establishment 
rates (COSEWIC 2003; discussed in the Conservation Biology section of this report) leave Porsild's bryum ill-equipped to recover from decline.

1. Recreational Traffic. - The preference of Porsild's bryum for undercut rock surfaces protects it from trampling, but the sheltering caves and striking waterfalls characteristic of these sites are attractive to humans. The entirety of two Alberta populations and three of four subpopulations in a third come in particularly close contact with recreational traffic. In the Evan-Thomas Provincial Recreation Area (Kananaskis Country), Porsild's bryum occurs at the main destination - a waterfall within $1.8 \mathrm{~km}$ of a major trailhead - along a very popular trail. Foot traffic at the base of the rock overhang supporting the majority of the population has virtually eliminated all plant matter, and J. Doubt observed more than 20 people exploring or taking shelter from rain in the shallow cave occupied by Porsild's bryum in the two hours it took to document the site. The trail continues upstream of the falls, and though it is less travelled, waterfalls on the upper section provide picturesque stopping places for hikers continuing onward. At least one of these upstream falls also supports a small subpopulation of Porsild's bryum (Appendix 2).

Trails in Whitehorse Creek Provincial Recreation Area and Whitehorse Wildland Park also bring hikers and campers in close proximity to Porsild's bryum sites. Beer bottles found periodically at Whitehorse Creek site 2 (Appendix 2) show that the site is a popular unsanctioned stopping place (J. Doubt pers. obs.; N. Cleavitt pers. comm.). Three falls in the Whitehorse Creek trail network that support Porsild's bryum are popular destinations for riders or hikers. The most vulnerable subpopulation in the Whitehorse Creek area occurs within the busy campground, where the species' overhanging rock substrate intervenes between two campsites, forming a convenient natural awning below which campfires and picnic tables have been observed (J. Doubt pers. obs.; N. Cleavitt and A. Dinwoodie pers. comm.). COSEWIC (2003) notes that the British Columbia population of Porsild's bryum is also threatened by recreational activity.

2. Natural Resource Development. - In 2004, a mine haul road (gravel surface) was constructed that passes close to two Porsild's bryum subpopulations in Whitehorse Creek Provincial Recreation Area, and one population in Mountain Park / Cardinal Divide. The haul road was built to support Elk Valley Coal's Cheviot Coal Mine. Despite concerns raised in COSEWIC (2003) regarding the position of the roadbed and the potential for blasting to destroy the unstable rock substrate, the haul road did not eliminate any known Porsild's bryum sites. However, it brings road traffic within less than $100 \mathrm{~m}$ of two populations (one of which consists of four subpopulations). The anticipated initial production rate of the mine is 1.4 million tonnes per year (Elk Valley Coal 2004), necessitating large mine vehicles that travel between the mine site and the Luscar processing plant, passing a given point along the route with what some sources report as a frequency of every nine minutes (e.g., Sierra Legal Defence Fund 2004); a mine representative who was asked to clarify this estimate declined response. The effect of road dust and exhaust on Porsild's bryum is not known, but the sensitivity of bryophytes to pollution is well documented (e.g., Rao 1982).

\section{Hydrology, Chemistry, Turbidity - Mosses} are widely known for their close association with local moisture and chemical conditions, and have been used as sensitive indicators of these substrate characteristics. The dependence of Porsild's bryum on a very narrow subset of stream/seepage habitats suggests that it is particularly sensitive to its growing conditions, making it critically vulnerable to changes in hydrology, chemistry and/or turbidity that may result from specific local disturbances or regional factors such as climate change or atmospheric pollution. 
COSEWIC (2003) identified turbidity resulting from off-highway vehicle traffic in the headwaters of streams supporting Porsild's bryum as a potential threat to the species. No other current threats to any Alberta Porsild's bryum population as a result of localized anthropogenic change in water quantity or quality are known. However, the potential for these kinds of changes to affect the species' persistence cannot be overemphasized, and downstream effects of mine activity and recreation in the Whitehorse Creek and Mountain Park / Cardinal Divide areas should be closely monitored. Consistent moisture through the growing season is essentialseasons of recent drought are thought to be responsible for population declines at some sites (COSEWIC 2003). Odland et al. (1991) reported dramatic decreases in bryophyte cover and richness in the spray zone of a Norway waterfall after 20 years of flow regulation (92\% reduction in mean annual discharge).

4. Natural Factors. - Porsild's bryum is naturally rare, and is limited by its own physiology, dispersal and/or establishment capabilities to few, disjunct sites. It belongs to a group of so-called "copper mosses" that is well known for its habitat specialization, rarity and wide disjunction (e.g., Shaw 1994, Shaw and Schneider 1995). As the focus of a doctoral thesis (Cleavitt 2002a), Porsild's bryum has undergone more scientific investigation than most Alberta moss species. Relevant findings of these investigations are highlighted in the preceding sections, but additional work is required. Factors accounting for the species' rarity, including its apparent habitat specificity and low rate of successful dispersal, should be researched in order to more fully characterize natural limitations and predict the effects of human disturbance and of potential management activities.

\section{STATUS DESIGNATIONS*}

1. Alberta. - Provincially, the Alberta Natural Heritage Information Centre ranks the species S1, reflecting the fact that there were until recently five or fewer occurrences (separated by a kilometre or more) known in the province (Vujnovic and Gould 2002). The species is not listed under Alberta's Wildlife Act.

\section{Other Areas. -}

National: In November 2003, Porsild's bryum was designated Threatened by the Committee on the Status of Endangered Wildlife in Canada (COSEWIC), based on a recent status report (COSEWIC 2003). Threatened status indicates that a species is likely to become Endangered (face imminent extirpation or extinction) if limiting factors are not reversed (COSEWIC 2005). The committee based its designation on the species' small population and fragmented distribution among five general areas of Canada, noting that natural and human threats to known populations exist. COSEWIC (2003) goes on to state that habitat quality has declined in two localities (one in each of Newfoundland and Alberta), and that only one of these two localities (that in Alberta) is protected.

At the time of this report, Porsild's bryum was undergoing public consultation in preparation for possible addition to Schedule 1-Canada's official listing of wildlife species at risk under the Species at Risk Act (Environment Canada 2004). Once a species is listed on Schedule 1 , measures to protect and recover the species (potential examples include the establishment of a recovery team, the collection of more detailed population information, and action to increase population size and number) are implemented for populations on federal land. Populations under provincial jurisdiction (such as Porsild's bryum in Alberta) are subject to provincial management decisions and enforcement,

\footnotetext{
* See Appendix 1 for definitions of selected status designations.
} 
including a recovery strategy process similar to that undertaken at the national level. A recovery strategy for Porsild's bryum in Newfoundland is in preparation (R. Belland pers. comm.).

Porsild's bryum is ranked $\mathrm{S} 1$ in British Columbia by the British Columbia Conservation Data Centre (BCCDC 2004) and S1 in Newfoundland by the Atlantic Canada Conservation Data Centre (ACCDC 2004). The species has yet to be ranked in Nunavut, and the Nunavut Wildlife Management Board has opposed the addition of Porsild's bryum to Canada's Species at Risk Act Schedule 1 on the basis of inadequate information and high potential that other unidentified populations exist (Government of Canada 2005).

International: Porsild's bryum is ranked G2 (imperilled) on a global scale-a rank that indicates that a species is at high risk of extinction because of factors such as restricted range, very few populations (often 20 or fewer) and steep declines (NatureServe 2004). In the United States, Porsild's bryum is ranked S1 in Montana (Montana Natural Heritage Program 2001), S2 in Colorado (Colorado Natural Heritage Program 2004), and is as yet unranked in Alaska, Utah, Wyoming and Michigan.

\section{RECENT MANAGEMENT IN ALBERTA}

No management activities focused on Porsild's bryum have been undertaken in Alberta. The main subpopulation of the Ribbon Creek occurrence of Porsild's bryum is noted in the management plan for Evan-Thomas Provincial Recreation Area (Alberta Community Development 2004), but no activities are proposed. A. Dinwoodie, volunteer steward of Whitehorse Wildland Park and past president of the Stewards of Alberta Protected Areas Association, confirms that her group is aware of the locations of populations (both within the park and in Mountain Park / Cardinal Divide) and periodically monitors activity near the sites (pers. comm.). The development of a recovery strategy by a COSEWIC-appointed recovery team will not begin until Porsild's bryum is appended to Schedule 1 , at an asyet-undetermined date. The projected date of commencement for management activities, therefore, is unknown. Cleavitt's (2002a) doctoral thesis, which illuminates several aspects of the species' ecology and rarity but does not deal directly with anthropogenic threats or management issues, remains the most comprehensive compendium of research on the species to date.

\section{SYNTHESIS}

Porsild's bryum is rare throughout its global range, occupying small, isolated sites often separated by hundreds or thousands of kilometres. Habitats in Canada and Alaska support the majority of the imperilled global population. Alberta, in turn, possesses the largest known Canadian population of Porsild's bryum, distributed among seven (eight including historical records) localities in the Rocky Mountains. Preserving Alberta's population of Porsild's bryum is critical to the national and global preservation of the species.

Porsild's bryum prefers very specific, very uncommon habitats. Although they have not been fully characterized by researchers, these habitats are known to be naturally unstable, and populations inhabiting them may fluctuate dramatically in response to natural disturbances. Nonetheless, no instances of natural extirpation have yet been documented. Porsild's bryum habitat is characterized by consistent moisture from seepage or splash throughout the growing season, making it particularly vulnerable to changes in water flow, chemistry or turbidity that may result from specific anthropogenic activities or from more general impacts such as drought resulting from climate change. Intensive human activity in the form of recreational and mine vehicle traffic coincides with known Alberta sites for the species. Researchers are not sufficiently 
certain of Porsild's bryum habitat preferences to be able to select sites for transplant, and transplant viability is low. Conservation of Alberta populations therefore relies on the preservation of existing habitats, including their natural moisture, chemistry, temperature and light regimes.

Although more search and research effort has been devoted to Porsild's bryum than to most other taxa of rare moss in Alberta, our understanding and management of Porsild's bryum distribution and abundance in Alberta would benefit from additional work in certain areas. Botanists should be alert for additional populations or subpopulations, particularly along the watercourses where records are already known. N. Cleavitt (pers. comm.) has searched several areas, including those between known records of the species that are less than $15 \mathrm{~km}$ apart (COSEWIC 2003). In Jasper National Park, N. Cleavitt (pers. comm.) looked for Porsild's bryum at Snake Indian Falls and Punchbowl Falls along the road to Miette Hotsprings (Jasper National Park). In the Whitehorse Creek area, she searched Whitehorse Creek up to the lower falls, Prospect Creek, Drummond Creek, Ruby Creek, Cardinal River and waterfalls along the McLeod River, as well as the unnamed creek supporting the Porsild's bryum population in Mountain Park / Cardinal Divide. However, additional sites, particularly in remote areas where few botanists have travelled, may yet be found. Travel upstream of known populations may also help to identify potential anthropogenic or natural threats to existing environmental conditions at sites currently supporting Porsild's bryum. Nonetheless, worldwide observations confirm that Porsild's bryum is truly rare.
The question of the correlation of Porsild's bryum and concentrations of heavy metals such as copper (either in the species' substrate or in the water that bathes it) should be addressed by systematic sampling of substrate and water at all known sites. Experiments to test the species' dependence would also be valuable. Consultation with a geologist would be of great benefit, both in determining the specific character of substrates where Porsild's bryum is known to occur and in predicting potential regions of occurrence based on the distribution of similar substrates in Alberta.

COSEWIC (2003) suggested several avenues of investigation to clarify the physiological and ecological requirements of Porsild's bryum. For example, experiments on propagule (spore or fragment) establishment, colony expansion, and population turnover with respect to competitive interactions, and environmental habitat parameters would help to pinpoint potential limiting factors. Studies in population genetics would help to characterize dispersal patterns among sites, and have been very successful in illuminating biogeographic histories of other copper mosses (e.g., Shaw and Schneider 1995). Long-term monitoring of (sub)populations to determine the amplitude and frequency of natural disturbancemediated changes in abundance would help to characterize the species' natural population dynamics so that they could be distinguished from the effects of human disturbance, and would help to identify the extremes of decline from which populations can recover. 


\section{LITERATURE CITED}

ACCDC. 2004. Atlantic Canada Conservation Data Centre web site. URL: http:// www.accdc.com/ [Data accessed September 2004].

Alberta Community Development. 2004. Evan-Thomas Provincial Recreation Area Management Plan. Alberta Community Development Parks and Protected Areas, Kananaskis Country. Canmore, AB. 38 pp.

Alberta Community Development. 2005. Parks and Protected Areas Management in Alberta. URL: http://www.cd.gov. ab.ca/preserving/parks/managing/ spectrumsites.asp\#wildland [Accessed January 2005].

Alberta Environmental Protection. 1996. The status of Alberta wildlife. Alberta Environmental Protection, Natural Resources Service, Wildlife Management Division. Edmonton, AB. 44 pp.

Alberta Forestry, Lands and Wildlife. 1991. The status of Alberta wildlife. Alberta Forestry, Lands and Wildlife, Fish and Wildlife Division. Edmonton, AB. 49 pp.

Alberta Natural Heritage Information Centre (ANHIC). 2004a. Rank Definitions. URL: $\quad$ http://www.cd.gov.ab.ca/ preserving/parks/anhic/definitions.asp [Last updated October 2002].

Alberta Natural Heritage Information Centre (ANHIC). 2004b. Parks and Protected Areas Division, Alberta Community Development. ANHIC Database Element Occurrence Report. [Data accessed August 2004 via personal communication with John Rintoul, ANHIC Co-ordinator.]
Alberta Sustainable Resource Development. 2001. The general status of Alberta wild species 2000 . Alberta Sustainable Resource Development, Fish and Wildlife Service, Edmonton, AB. 46 pp.

Alberta Wilderness Association. 2006. Cardinal divide. URL: http://issues. albertawilderness.ca/CD/cardinal divide.htm [Accessed June 2006].

Andrews, A.L. 1932. The Mielichhoferia of northern North America. The Bryologist 35:38-41.

Belland, R.J. 1987. The disjunct moss flora of the Gulf of St. Lawrence region: glacial and postglacial dispersal and migrational histories. Journal of the Hattori Botanical Laboratory 63:1-76.

Bird, C.D. 1967. The mosses collected by Thomas Drummond in western Canada, 1825-1827. The Bryologist 70:262-266.

Bird, C.D. 1968. New or otherwise interesting mosses from Alberta. The Bryologist 71:358-361.

Brassard, G.R. 1969. Mielichhoferia elongata, a copper moss new to North America, found in Arctic Canada. Nature 222:584-585.

Brassard, G.R. 1971. The mosses of northern Ellesmere Island, Arctic Canada. I. Ecology and phytogeography, with an analysis for the Queen Elizabeth Islands. The Bryologist 74:233-281.

Brassard, G.R., and T. Hedderson. 1983. The distribution of Mielichhoferia macrocarpa, a North American endemic moss. The Bryologist 86:273275. 
Brooks, R.R. 1971. Bryophytes as a guide to mineralization. New Zealand Journal of Botany 9:674-677.

Brown, D.H. 1982. Mineral nutrition. Pages 383-444 in Smith, A.J.E. (ed.). Bryophyte ecology. Chapman and Hall, London, U.K. 511 pp.

BCCDC. 2004. British Columbia Conservation Data Centre web site. URL: http:// srmwww.gov.bc.ca/cdc/[Dataaccessed September 2004].

Cleavitt, N.L. 2001. Disentangling moss species limitations: the role of physiologicallybased substrate specificity for six species occurring on substrates with varying $\mathrm{pH}$ and percent organic matter. The Bryologist 104:59-68.

Cleavitt, N.L. 2002a. Relating rarity and phylogeny to the autecology of mosses: a comparative study of three rare-common species pairs in the Front Ranges of Alberta, Canada. $\mathrm{PhD}$ Thesis, University of Alberta. 293 pp.

Cleavitt, N.L. 2002b. Stress tolerance of rare and common moss species in relation to their occupied environments and asexual dispersal potential. Journal of Ecology 90:785-795.

Colorado Natural Heritage Program. 2004. Online listing of tracked non-vascular plants. URL: http://www.cnhp. colostate.edu/tracking/nonvascular. html [Data accessed September 2004].

COSEWIC. 2003. COSEWIC assessment and status report on Porsild's bryum Mielichhoferia macrocarpa in Canada. Committee on the Status of Endangered Wildlife in Canada. Ottawa. vi +22 pp. URL: www.sararegistry.gc.ca/status/ status_e.cfm [Accessed August 2004].
COSEWIC. 2005. Database. Committee on the Status of Endangered Wildlife in Canada. URL: http://www.cosewic. gc.ca [Data accessed September 2004].

Cox, C.J., B. Goffinet, A.E. Newton, A.J. Shaw and T. A. Hedderson. 2000. Phylogenetic relationships among the diplolepideous-alternate mosses (Bryidae) inferred from nuclear and chloroplast DNA sequences. The Bryologist 103:224-241.

Cox, C.J., and T.A. Hedderson. 2003. Phylogenetic relationships within the moss family Bryaceae based on chloroplast DNA evidence. Journal of Bryology 25:31-40.

Crum, H.A., and L.E. Anderson. 1981. Mosses of eastern North America. Columbia University Press, New York, U.S.A. $1328 \mathrm{pp}$.

During, H.J. 1992. Ecological classification of bryophytes and lichens. Pages 1-31 in Bates, J.W., and A.M. Farmer (eds.). Bryophytes and Lichens in a Changing Environment. Oxford University Press, New York, USA. 404 pp.

Elk Valley Coal. 2004. Cardinal River Operations web page. URL: http:// www.elkvalleycoal.ca/cache/page 1261-1315.html [Accessed October 2004].

Environment Canada. 2004. Species At Risk web site. URL: http://www. speciesatrisk.gc.ca/default_e.cfm [Data accessed September 2004].

Flowers, S. 1973. Mosses: Utah and the West. Brigham Young University Press, Provo. $x i i+567 \mathrm{pp}$ 
Glime, J.M., and A.D. Slavick. 1985. A checklist of the bryophytes and their critical localities in the Keweenaw Peninsula, Michigan. The Michigan Botanist 24:153-163.

Government of Canada. 2005. Regulatory Impact Analysis Statement. Canada Gazette Part 2, Volume 39, Number 15 (July 27 2005). URL: http:// www.sararegistry.gc.ca/regs_orders/ showHTML_e.cfm? ocid= 1471 [Accessed January 2006].

Hallingbäck, T., N. Hodgetts, G. Raeymaekers, R. Shumacker, C. Sérgio, L. Söderström, N. Stewart and J. Vána. 1998. Guidelines for application of the revised IUCN threat categories to bryophytes. Lindbergia 23:6-12.

Hortiplex. 2004. On-line plants database. URL: http://hortiplex.gardenweb. com/plants/p1/gw1025914.html [Data accessed October 2004].

Ignatov, M.S., and O.M. Afonina. 1992. Checklist of the mosses of the former U.S.S.R. Arctoa 1:1-85.

Lawton, E. 1971. Moss flora of the Pacific Northwest. Hattori Botanical Laboratory, Nichinan, Miyazaki, Japan. 389 pp + 195 pl.

Longton, R.E. 1976. Reproductive biology and evolutionary potential in bryophytes. Journal of the Hattori Botanical Laboratory 41:205-223.

Luckman, B., and T. Kavanagh. 2000. Impact of climate fluctuations on mountain environments in the Canadian Rockies. Ambio 29:371-380.

Marquis, R.J., andE.G. Voss. 1981.Distributions of some western North American plants disjunct in the Great Lakes region. Michigan Botanist 20:53-82.

Missouri Botanical Garden. 2004. On-line herbarium records. URL: http://mobot. mobot.org/W3T/Search/most.html [Data accessed October 2004].

Montana Natural Heritage Program. 2001. Online list of plant species of concern. URL: $\quad$ http://nhp.nris.state.mt.us/ plants/reports/Plant_List_2001.pdf [Data accessed October 2004].

National Research Council. 1995. Science and the Endangered Species Act. National Academy Press, Washington, DC. 271 pp.

Nature Canada. 2005. Cheviot media backgrounder. URL: http://www. cnf.ca/newsroom/nov_02_04a.html [Accessed June 2006].

NatureServe. 2004. A habitat-based strategy for delimiting plant element occurrences: guidance from the 2004 working group. URL: http://www.natureserve. org/library/deliminting_plant_eos_ Oct_2004.pdf.

NatureServe. 2005. NatureServe Explorer: an online encyclopedia of life [web application]. Version 4.6. Arlington, Virginia, USA: NatureServe. URL: http://www.natureserve.org/explorer [Last updated: October 2005].

Odland, A., H.H. Birks, A. Botnen, T. Toensberg and O. Velve. 1991. Vegetation change in the spray zone of a waterfall following river regulation in Aurland, western Norway. Regulated Rivers: Research and Management 6:147162. 
Packer, J.G., and D.H. Vitt. 1974. Mountain Park: a plant refugium in the Canadian Rocky Mountains. Canadian Journal of Botany 52:1393-1409.

Persson, H. 1956. Studies in the "copper mosses". Journal of the Hattori Botanical Laboratory 17:1-18.

Rao, D.N. 1982. Responses of bryophytes to air pollution. Pages 445-472 in Smith, A.J.E. (ed.). Bryophyte ecology. Chapman and Hall, London, U.K. 511 pp.

Roberts, D.C. 1996. Geology of eastern North America. Houghton Mifflin Company, New York. 402 pp.

Rohrer, J.R. 1982. Sporophyte production and sexuality of mosses in two northern Michigan habitats. The Bryologist 85:394-400.

Rood, S.B., G.M. Samuelson, J.K. Weber and K.A. Wywrot. 2005. Twentiethcentury decline in streamflows from the hydrographic apex of North America. Journal of Hydrology 306:215-233.

Schofield, W.B., and H.A. Crum. 1972. Disjunctions in bryophytes. Annals of the Missouri Botanical Garden 59:174202.

Shacklette, H.T. 1967. Copper mosses as indicators of metal concentrations. U.S. Geological Survey Bulletin 1198G. $18 \mathrm{pp}$.

Shacklette, H.T. 1969. Vegetation of Amchitka Island, Aleutian Islands, Alaska. U.S. Geological Survey Professional Paper 648. $66 \mathrm{pp}$.

Shaw, A.J. 1994. Systematics of Mielichhoferia (Bryaceae: Musci) II. Morphological variation among disjunct populations of M. elongata and $M$. mielichhoferiana. The Bryologist 97:47-55.

Shaw, A.J. 2001. Biogeographic patterns and cryptic speciation in bryophytes. Journal of Biogeography 28:253-261.

Shaw, A.J., and H. Crum. 1984. Peristome homology in Mielichhoferia and a taxonomic account of the North American species. Journal of the Hattori Botanical Laboratory 57:363381.

Shaw, A.J., and P.E. Rooks. 1994. Systematics of Mielichhoferia (Bryaceae:Musci) I. Morphological and genetic analyses of M. elongata and M. mielichhoferiana. The Bryologist 97:1-12.

Shaw, A.J., and R.E. Schneider. 1995. Genetic biogeography of the rare "copper moss", Mielichhoferia elongata (Bryaceae). American Journal of Botany 82:8-17.

Sierra Club of Canada. 2004. Making Mountain Park a reality. URL: http://www. fanweb.ca/cheviot/index_html?main_ page_name $=$ scientists_statement.htm [Accessed June 2006].

Sierra Legal Defence Fund. 2004. Media backgrounder: Cheviot Open-Pit Coal Mine Project. URL: http://www. sierralegal.org/m_archive/bgr04_11_ 02.html [Accessed January 2005].

Steere, W.C. 1978. The mosses of Arctic Alaska. Bryophytorum Bibliotheca 14. J. Cramer, Vaduz. 508 pp.

Stewart, I.T., D.R. Cayan and M.D. Dettinger. 2004. Changes in snowmelt runoff timing in western North America under 
a "business as usual" climate change scenario. Climate Change 62:217-232.

Strong, W.L. 1999. Mountain Park area: a plant refugium in the Canadian Rocky Mountains? Journal of Biogeography 26:413-423.

Vujnovic, K., and J. Gould. 2002. Alberta Natural Heritage Information Centre Tracking and Watch Lists - Vascular Plants, Mosses, Liverworts, and Hornworts. Alberta Community Development Parks and Protected Areas, Edmonton. URL: http://www. cd.gov.ab.ca/preserving/parks/anhic/ flashindex.asp [Data accessed July 2004].
Webster, H.J. 1985. Elemental analyses of Pohlia nutans growing on coal seeps in Pennsylvania. Journal of the Hattori Botanical Laboratory 58:207-224.

Wells, J.R., and P.W. Thompson. 1974. Vegetation and flora of Keweenaw County, Michigan. The Michigan Botanist 13:107-151. 
Appendix 1. Definitions of selected legal and protective designations.

A. The General Status of Alberta Wild Species 2000 (after Alberta Sustainable Resource Development 2001)

\begin{tabular}{|l|l|l|}
\hline 2000 Rank & 1996 Rank & Definitions \\
\hline At Risk & Red & $\begin{array}{l}\text { Any species known to be } \text { At Risk after formal detailed status } \\
\text { assessment and designation as Endangered or Threatened in } \\
\text { Alberta. }\end{array}$ \\
\hline May Be At Risk & Blue & $\begin{array}{l}\text { Any species that may be at risk of extinction or extirpation, and is } \\
\text { therefore a candidate for detailed risk assessment. }\end{array}$ \\
\hline Sensitive & Yellow & $\begin{array}{l}\text { Any species that is not at risk of extinction or extirpation but may } \\
\text { require special attention or protection to prevent it from becoming } \\
\text { at risk. }\end{array}$ \\
\hline Secure & Any species that is not At Risk, May Be At Risk or Sensitive. \\
\hline Undetermined & $\begin{array}{l}\text { Status } \\
\text { Undetermined }\end{array}$ & $\begin{array}{l}\text { Any species for which insufficient information, knowledge or data } \\
\text { is available to reliably evaluate its general status. }\end{array}$ \\
\hline Not Assessed & $\mathrm{n} / \mathrm{a}$ & $\begin{array}{l}\text { Any species known or believed to be present but which has not yet } \\
\text { been evaluated. }\end{array}$ \\
\hline Exotic/Alien & $\mathrm{n} / \mathrm{a}$ & Any species that has been introduced as a result of human activities. \\
\hline Extirpated/Extinct & $\mathrm{n} / \mathrm{a}$ & $\begin{array}{l}\text { Any species no longer thought to be present in Alberta (Extirpated }) \\
\text { or no longer believed to be present anywhere in the world (Extinct) }\end{array}$ \\
\hline Accidental/Vagrant & $\mathrm{n} / \mathrm{a}$ & $\begin{array}{l}\text { Any species occurring infrequently and unpredictably in Alberta, } \\
\text { i.e., outside its usual range. }\end{array}$ \\
\hline
\end{tabular}

\section{B. Alberta Wildlife Act/Regulation}

Species designated as Endangered under Alberta's Wildlife Act include those listed as Endangered or Threatened in the Wildlife Regulation.

\begin{tabular}{|l|l|}
\hline Endangered & $\begin{array}{l}\text { A species whose present existence in Alberta is in danger of extinction within the next } \\
\text { decade. }\end{array}$ \\
\hline Threatened & $\begin{array}{l}\text { A species that is likely to become endangered if the factors causing its vulnerability } \\
\text { are not reversed. }\end{array}$ \\
\hline
\end{tabular}

\section{Committee on the Status of Endangered Wildlife in Canada (after COSEWIC 2005)}

\begin{tabular}{|l|l|}
\hline Extinct & A species that no longer exists. \\
\hline Extirpated & A species that no longer exists in the wild in Canada, but occurs elsewhere. \\
\hline Endangered & A species facing imminent extirpation or extinction. \\
\hline Threatened & A species that is likely to become endangered if limiting factors are not reversed. \\
\hline Special Concern & $\begin{array}{l}\text { A species that may become threatened or endangered because of a combination of } \\
\text { biological characteristics and identified threats. }\end{array}$ \\
\hline Not at Risk & $\begin{array}{l}\text { A species that has been evaluated and found to be not at risk given current } \\
\text { circumstances. }\end{array}$ \\
\hline Data Deficient & $\begin{array}{l}\text { A species for which there is inadequate information to make a direct, or indirect, } \\
\text { assessment of its risk of extinction. }\end{array}$ \\
\hline
\end{tabular}


Appendix 1 continued.

D. Heritage Status Ranks: Global (G), National (N), Sub-National (S) (after Alberta Natural Heritage Information Centre 2004a, NatureServe 2005)

\begin{tabular}{|l|l|}
\hline G1/N1/S1 & $\begin{array}{l}5 \text { or fewer occurrences or only a few remaining individuals. May be especially } \\
\text { vulnerable to extirpation because of some factor of its biology. }\end{array}$ \\
\hline G2/N2/S2 & $\begin{array}{l}6 \text { to } 20 \text { or fewer occurrences or with many individuals in fewer locations. May be } \\
\text { especially vulnerable to extirpation because of some factor of its biology. }\end{array}$ \\
\hline G3/N3/S3 & $\begin{array}{l}21 \text { to } 100 \text { occurrences, may be rare and local throughout its range, or in a restricted } \\
\text { range (may be abundant in some locations). May be susceptible to extirpation } \\
\text { because of large-scale disturbances. }\end{array}$ \\
\hline G4/N4/S4 & Typically > 100 occurrences. Apparently secure. \\
\hline G5/N5/S5 & Typically > 100 occurrences. Demonstrably secure. \\
\hline GX/NX/SX & Believed to be extinct or extirpated, historical records only. \\
\hline GH/NH/SH & Historically known, may be relocated in the future. \\
\hline GNR/NNR/SNR & Unranked-conservation status not yet assessed. \\
\hline
\end{tabular}

E. United States Endangered Species Act (after National Research Council 1995)

\begin{tabular}{|l|l|}
\hline Endangered & $\begin{array}{l}\text { Any species which is in danger of extinction throughout all or a significant portion of } \\
\text { its range. }\end{array}$ \\
\hline Threatened & $\begin{array}{l}\text { Any species which is likely to become an endangered species within the foreseeable } \\
\text { future throughout all or a significant portion of its range. }\end{array}$ \\
\hline
\end{tabular}




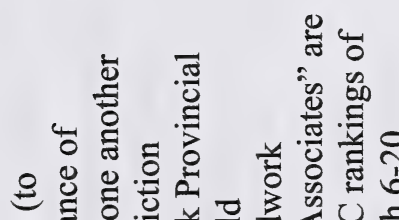

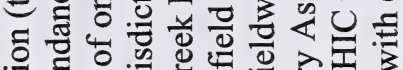

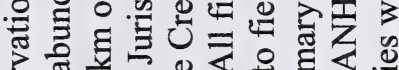

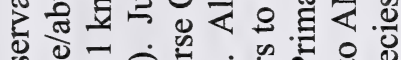

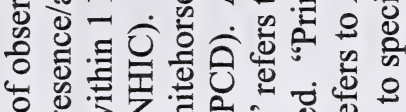

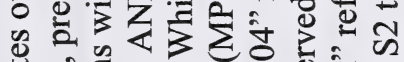

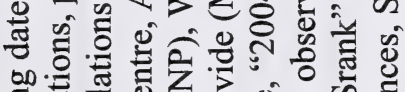
on. 䒠

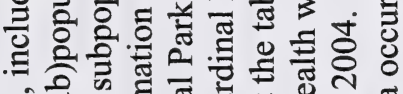

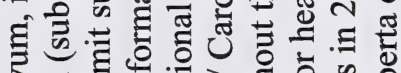

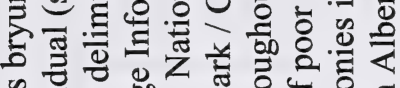

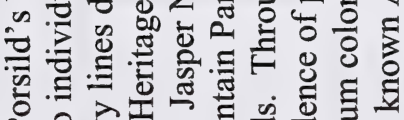
웡

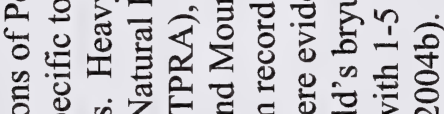

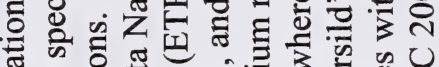
क क

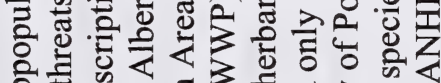

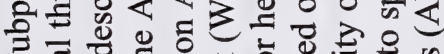
可. 뜬 可

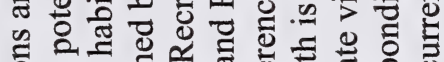

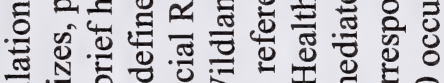

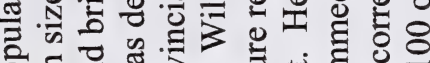

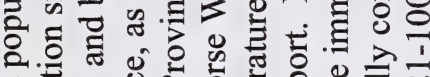

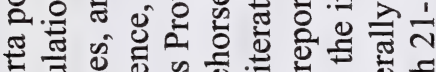

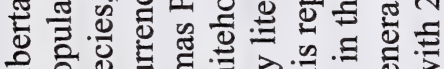

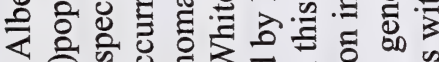
定

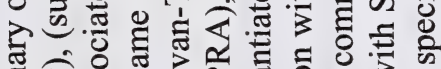
西 空言

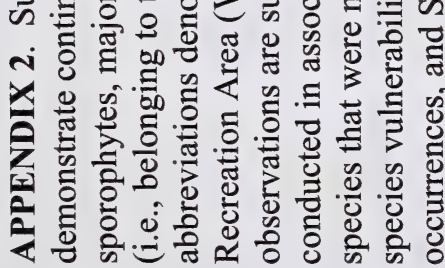

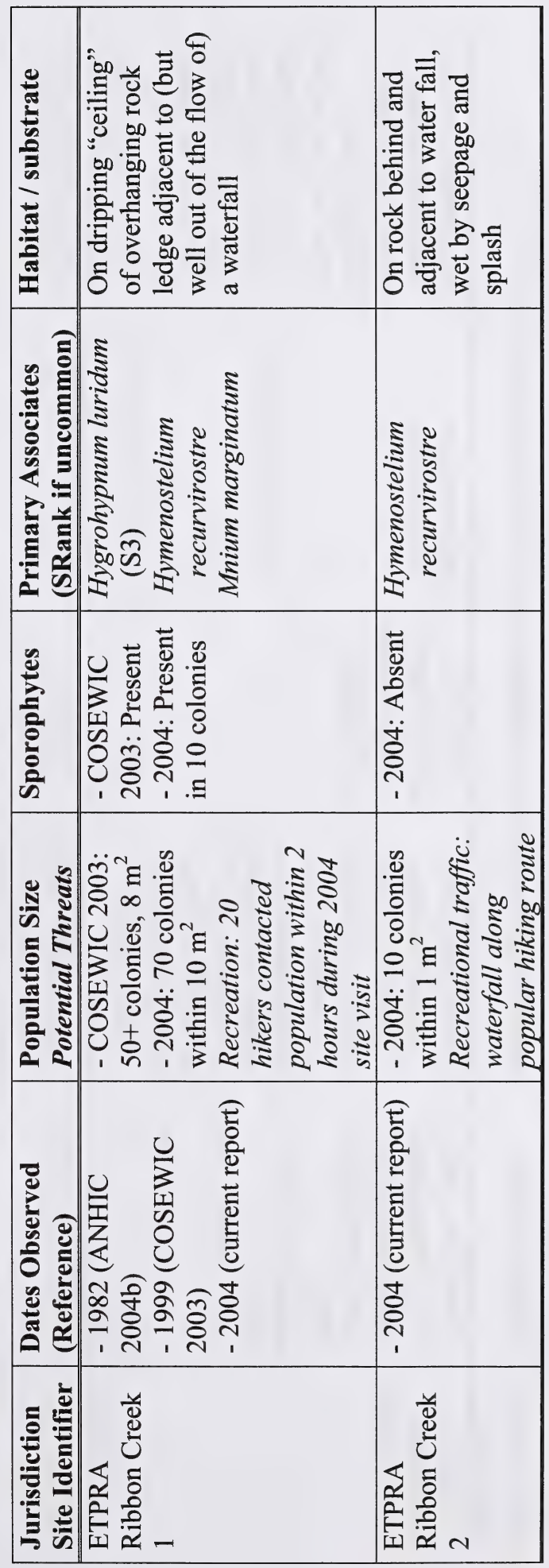




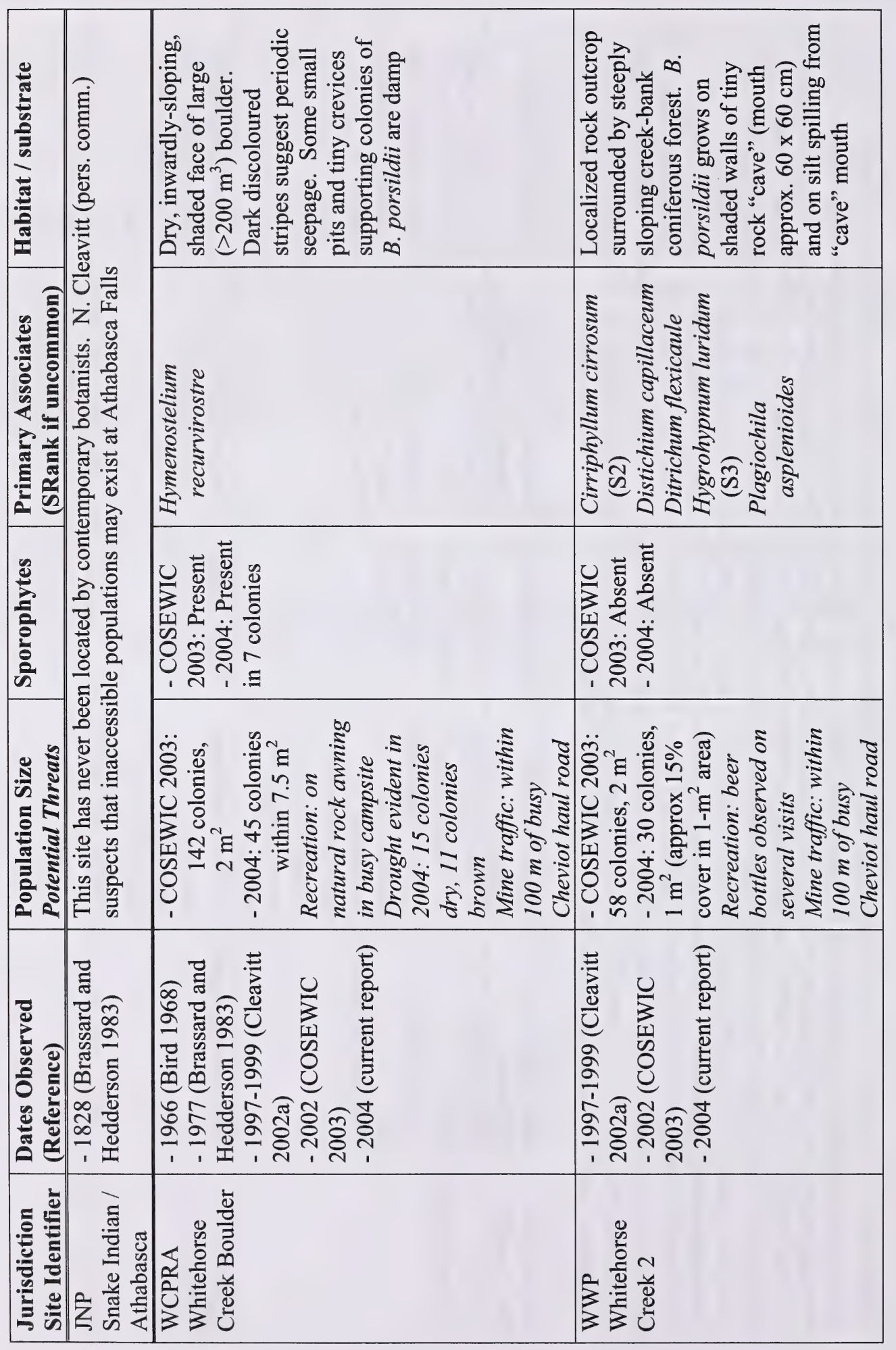




\begin{tabular}{|c|c|c|}
\hline 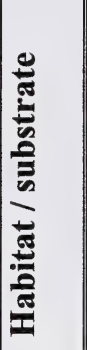 & 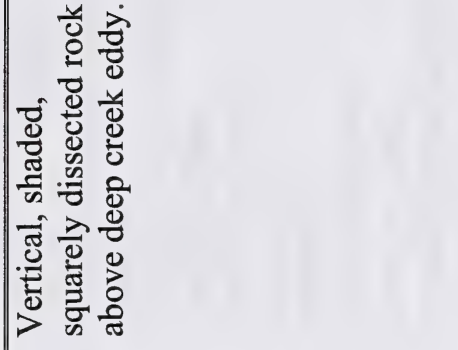 & 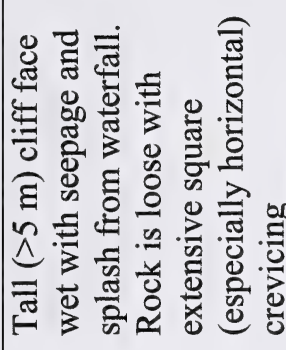 \\
\hline 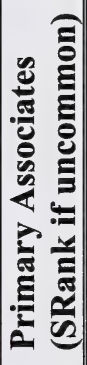 & 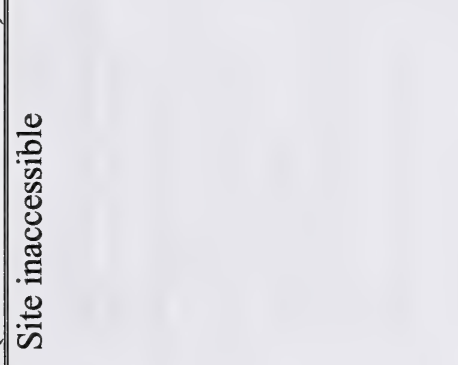 & 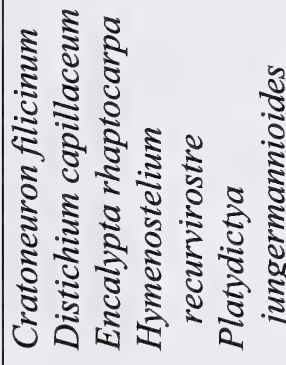 \\
\hline 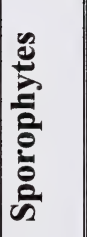 & 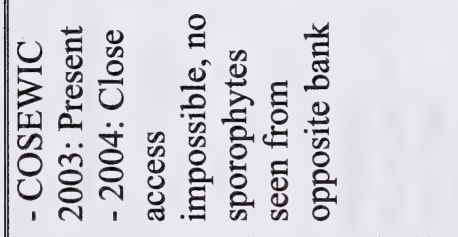 & 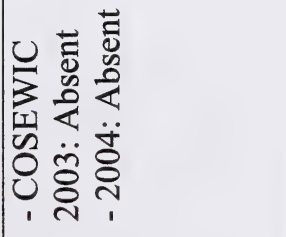 \\
\hline 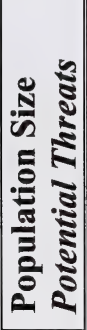 & 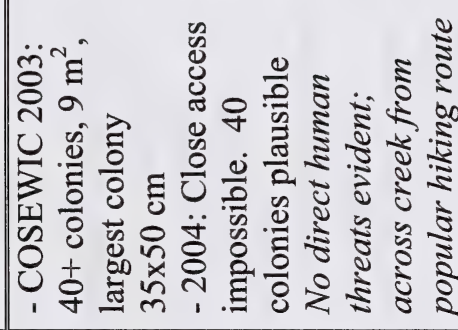 & 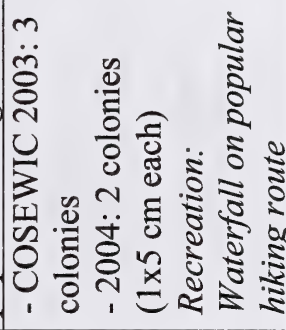 \\
\hline 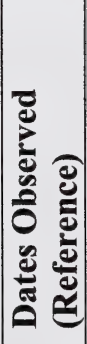 & 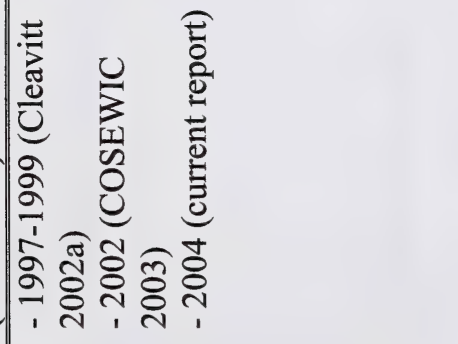 & 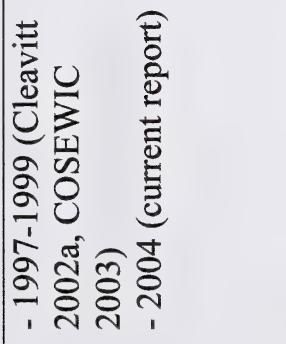 \\
\hline 苋 & 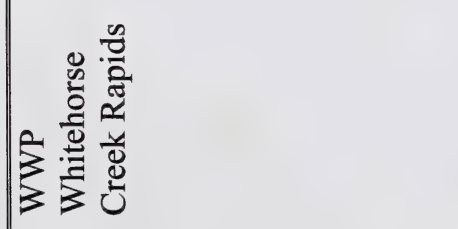 & 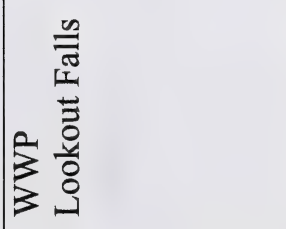 \\
\hline
\end{tabular}




\begin{tabular}{|c|c|c|}
\hline 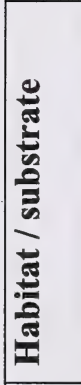 & 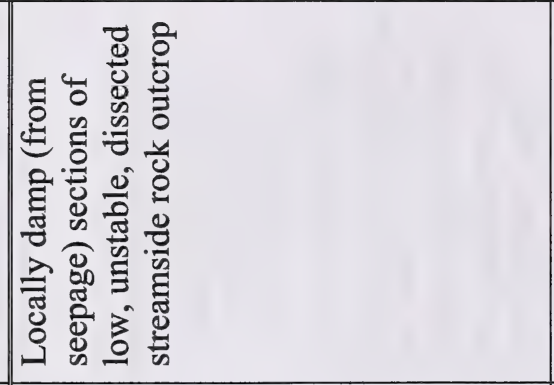 & 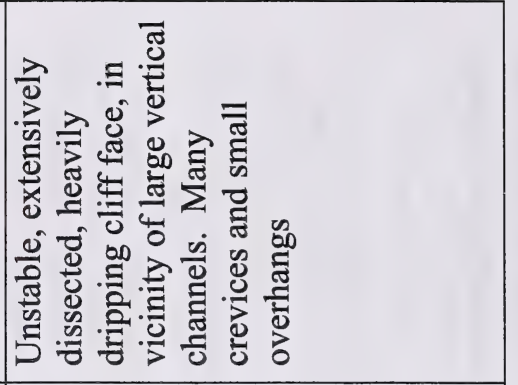 \\
\hline 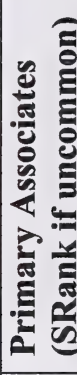 & 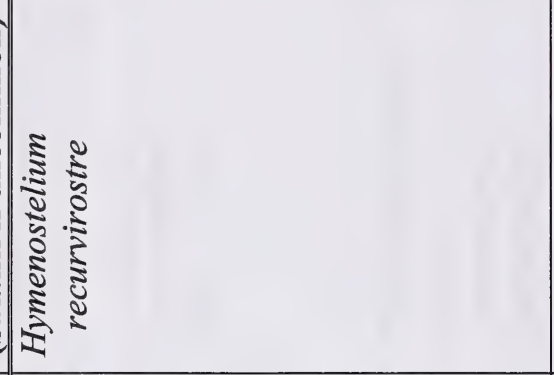 & 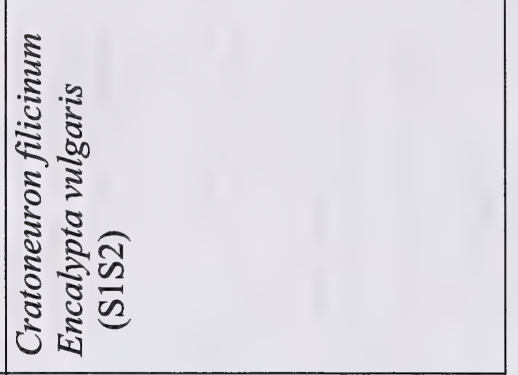 \\
\hline 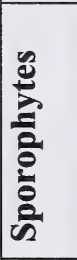 & 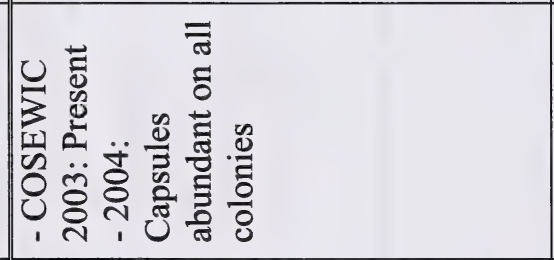 & 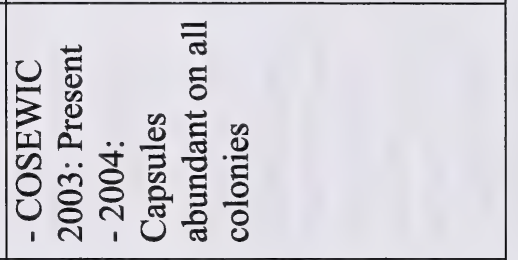 \\
\hline & 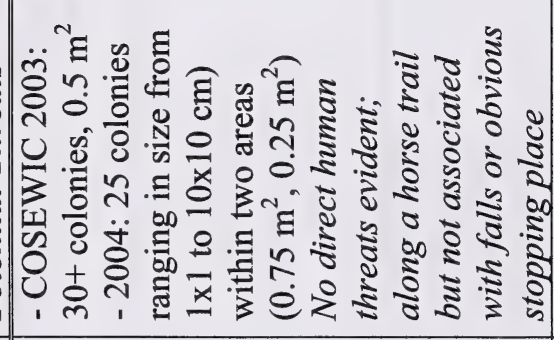 & 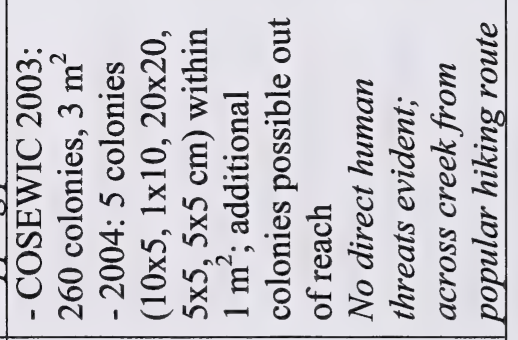 \\
\hline 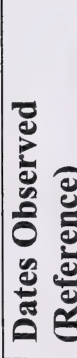 & 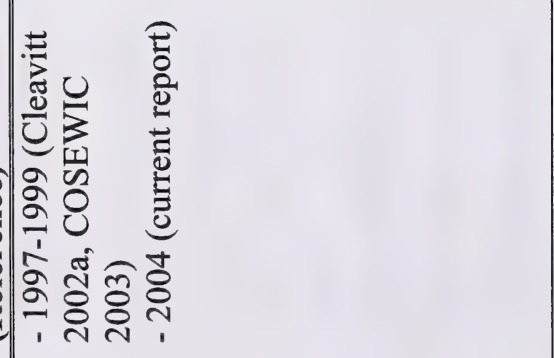 & 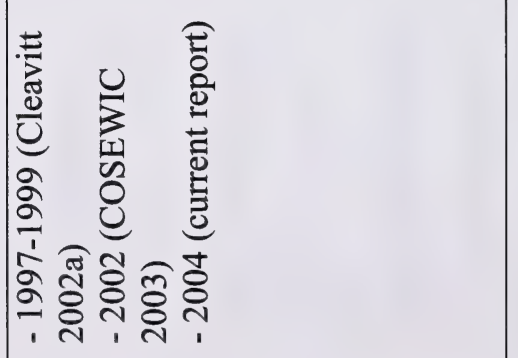 \\
\hline & 递 & 离 \\
\hline
\end{tabular}




\begin{tabular}{|c|c|c|}
\hline 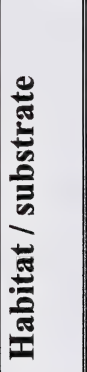 & 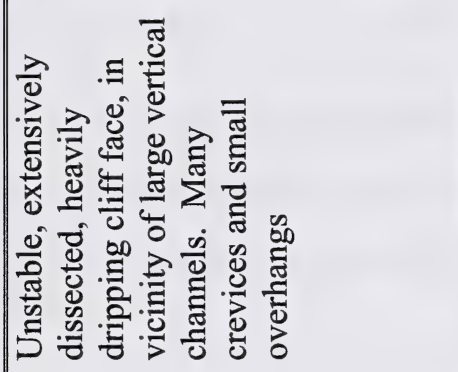 & 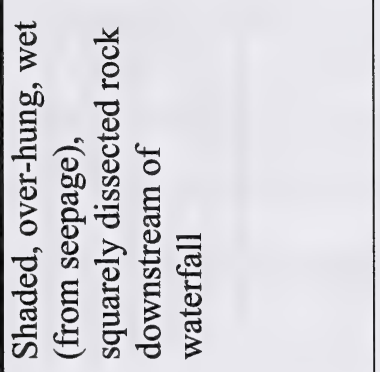 \\
\hline 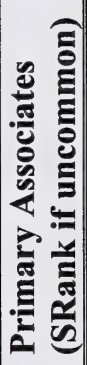 & 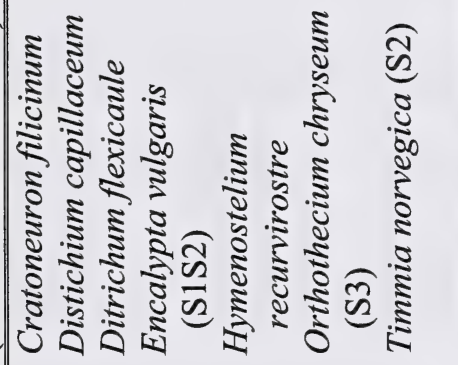 & 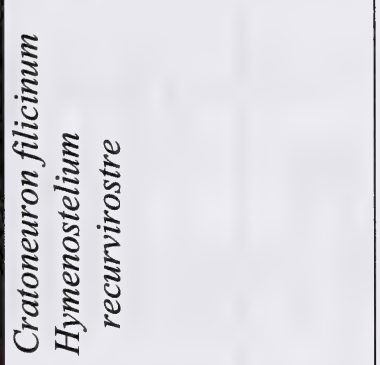 \\
\hline 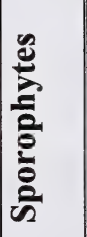 & 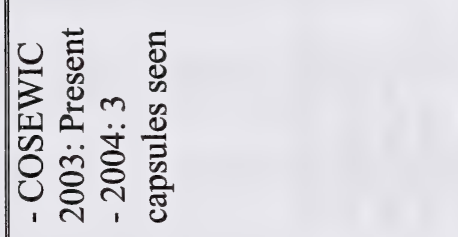 & 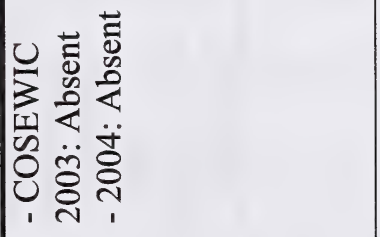 \\
\hline 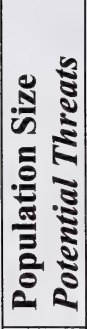 & 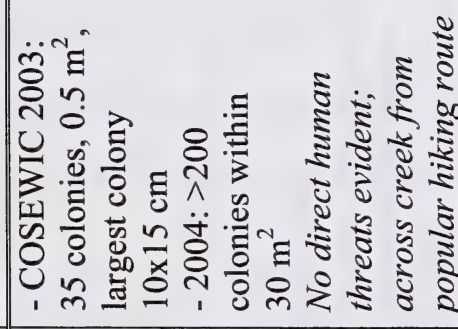 & 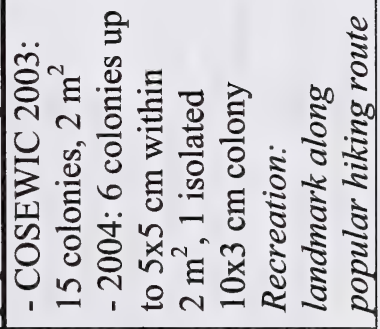 \\
\hline 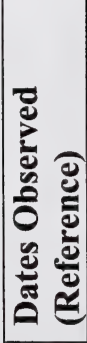 & 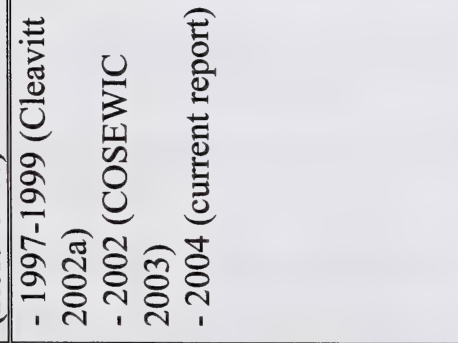 & 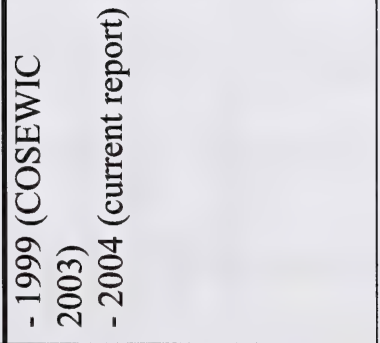 \\
\hline 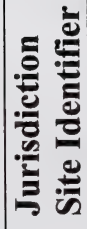 & 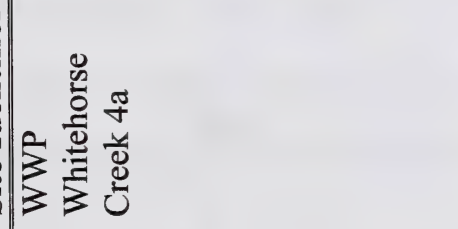 & 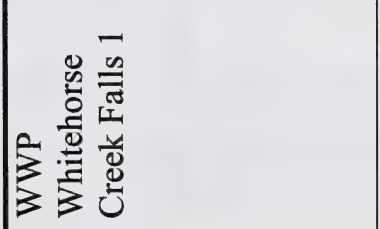 \\
\hline
\end{tabular}




\begin{tabular}{|c|c|c|}
\hline 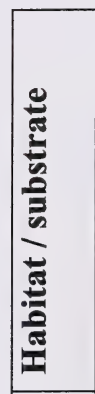 & 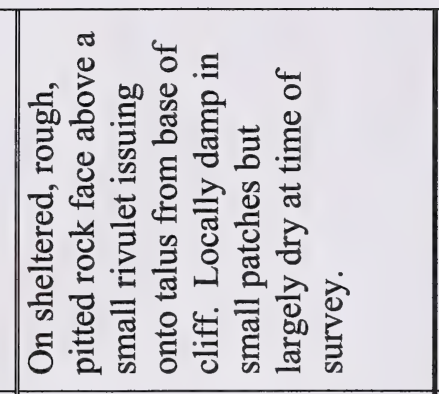 & 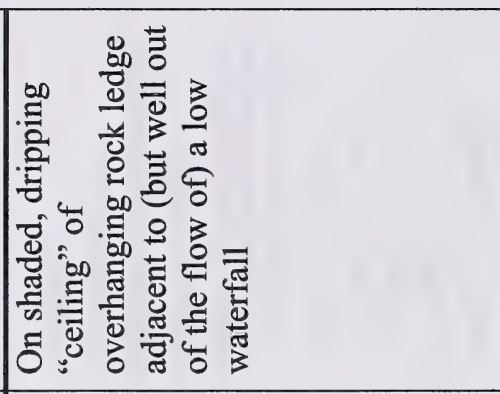 \\
\hline 要 & 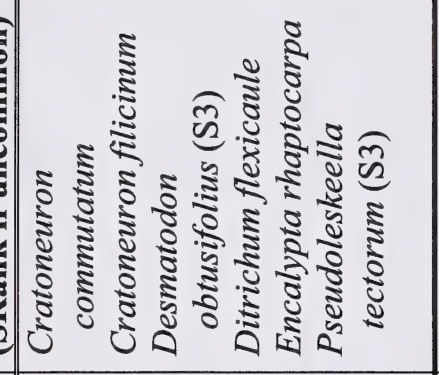 & 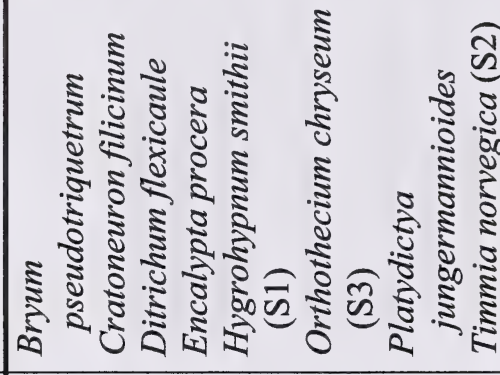 \\
\hline 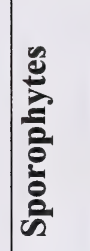 & 苍葶 & 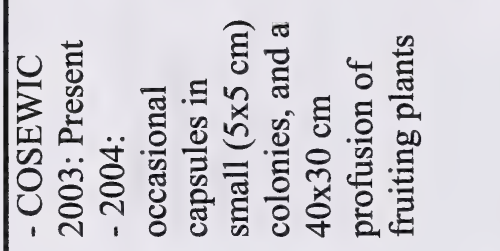 \\
\hline 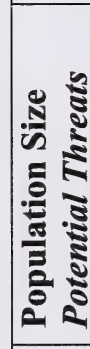 & 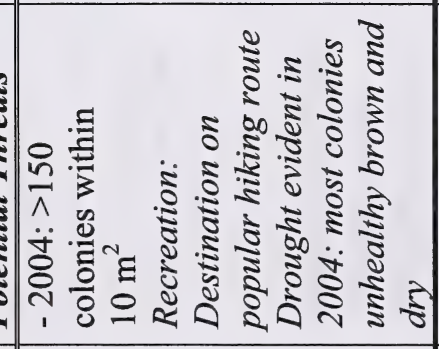 & 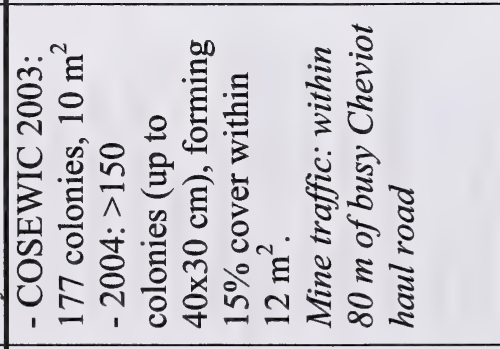 \\
\hline & 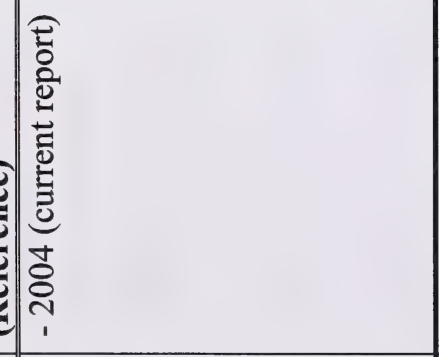 & 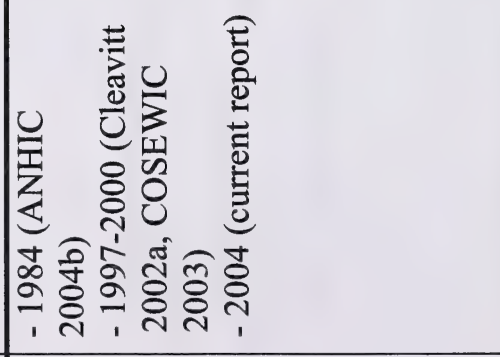 \\
\hline 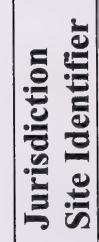 & 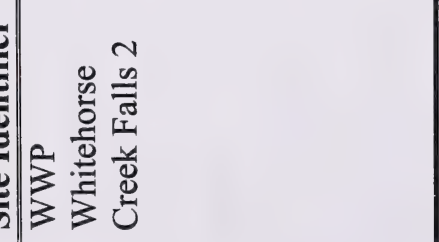 & 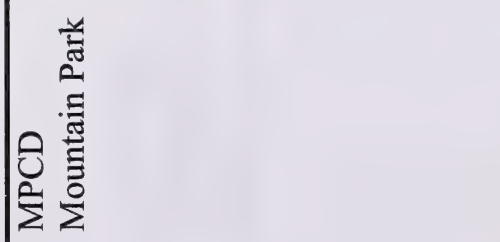 \\
\hline
\end{tabular}




\section{List of Titles in This Series}

(as of June 2006)

No. 1 Status of the Piping Plover (Charadrius melodus) in Alberta, by David R. C. Prescott. 19 pp. (1997)

No. 2 Status of the Wolverine (Gulo gulo) in Alberta, by Stephen Petersen. 17 pp. (1997)

No. 3 Status of the Northern Long-eared Bat (Myotis septentrionalis) in Alberta, by M. Carolina Caceres and M. J. Pybus. 19 pp. (1997)

No. 4 Status of the Ord's Kangaroo Rat (Dipodomys ordii) in Alberta, by David L. Gummer. 16 pp. (1997)

No. 5 Status of the Eastern Short-horned Lizard (Phrynosoma douglassii brevirostre) in Alberta, by Janice D. James, Anthony P. Russell and G. Lawrence Powell. 20 pp. (1997)

No. 5 Update 2004. Status of the Short-horned Lizard (Phrynosoma hernandesi) in Alberta. Alberta Sustainable Resource Development. 27 pp. (2004)

No. 6 Status of the Prairie Rattlesnake (Crotalus viridis viridis) in Alberta, by Sheri M. Watson and Anthony P. Russell. 26 pp. (1997)

No. 7 Status of the Swift Fox (Vulpes velox) in Alberta, by Susan E. Cotterill. 17 pp. (1997)

No. 8 Status of the Peregrine Falcon (Falco peregrinus anatum) in Alberta, by Petra Rowell and David P. Stepnisky. 23 pp. (1997)

No. 9 Status of the Northern Leopard Frog (Rana pipiens) in Alberta, by Greg Wagner. 46 pp. (1997)

No. 9 Update 2003. Status of the Northern Leopard Frog (Rana pipiens) in Alberta. Alberta Sustainable Resource Development. 61 pp. (2003)

No. 10 Status of the Sprague's Pipit (Anthus spragueii) in Alberta, by David R. C. Prescott. 14 pp. (1997)

No. 11 Status of the Burrowing Owl (Speotyto cunicularia hypugaea) in Alberta, by Troy I. Wellicome. $21 \mathrm{pp}$. (1997)

No. 11 Update 2005. Status of the Burrowing Owl (Athene cunicularia) in Alberta. Alberta Sustainable Resource Development and Alberta Conservation Association. 28 pp. (2005)

No. 12 Status of the Canadian Toad (Bufo hemiophrys) in Alberta, by Ian M. Hamilton, Joann L. Skilnick, Howard Troughton, Anthony P. Russell, and G. Lawrence Powell. 30 pp. (1998)

No. 13 Status of the Sage Grouse (Centrocercus urophasianus urophasianus) in Alberta, by Cameron L. Aldridge. 23 pp. (1998)

No. 14 Status of the Great Plains Toad (Bufo cognatus) in Alberta, by Janice D. James. 26 pp. (1998)

No. 15 Status of the Plains Hognose Snake (Heterodon nasicus nasicus) in Alberta, by Jonathan Wright and Andrew Didiuk. 26 pp. (1998)

No. 16 Status of the Long-billed Curlew (Numenius americanus) in Alberta, by Dorothy P. Hill. 20 pp. (1998)

No. 17 Status of the Columbia Spotted Frog (Rana luteiventris) in Alberta, by Janice D. James. 21 pp. (1998) 
No. 18 Status of the Ferruginous Hawk (Buteo regalis) in Alberta, by Josef K. Schmutz. 18 pp. (1999)

No. 18 Update 2006. Status of the Ferruginous Hawk (Buteo regalis) in Alberta. Alberta Sustainable Resource Development and Alberta Conservation Association. 22 pp. (2006)

No. 19 Status of the Red-tailed Chipmunk (Tamias ruficaudus) in Alberta, by Ron Bennett. 15 pp. (1999)

No. 20 Status of the Northern Pygmy Owl (Glaucidium gnoma californicum) in Alberta, by Kevin C. Hannah. 20 pp. (1999)

No. 21 Status of the Western Blue Flag (Iris missouriensis) in Alberta, by Joyce Gould. 22 pp. (1999)

No. 21 Update 2005. Status of the Western Blue Flag (Iris missouriensis) in Alberta. Alberta Sustainable Resource Development and Alberta Conservation Association. 29 pp. (2005)

No. 22 Status of the Long-toed Salamander (Ambystoma macrodactylum) in Alberta, by Karen L. Graham and G. Lawrence Powell. 19 pp. (1999)

No. 23 Status of the Black-throated Green Warbler (Dendroica virens) in Alberta, by Michael R. Norton. 24 pp. (1999)

No. 24 Status of the Loggerhead Shrike (Lanius ludovicianus) in Alberta, by David R. C. Prescott and Ronald R. Bjorge. 28 pp. (1999)

No. 25 Status of the Plains Spadefoot (Spea bombifrons) in Alberta, by Richard D. Lauzon. 17 pp. (1999)

No. 26 Status of the Trumpeter Swan (Cygnus buccinator) in Alberta, by M. Lynne James. 21 pp. (2000)

No. 27 Status of the Pygmy Whitefish (Prosopium coulteri) in Alberta, by William C. Mackay. 16 pp. (2000)

No. 28 Status of the Short-eared Owl (Asio flammeus) in Alberta, by Kort M. Clayton. 15 pp. (2000)

No. 29 Status of the Willow Flycatcher (Empidonax traillii) in Alberta, by Bryan Kulba and W. Bruce McGillivray. 15 pp. (2001)

No. 30 Status of the Woodland Caribou (Rangifer tarandus caribou) in Alberta, by Elston Dzus. 47 pp. (2001)

No. 31 Status of the Western Spiderwort (Tradescantia occidentalis) in Alberta, by Bonnie Smith. 12 pp. (2001)

No. 32 Status of the Bay-breasted Warbler (Dendroica castanea) in Alberta, by Michael Norton. 21 pp. (2001)

No. 33 Status of the Cape May Warbler (Dendroica tigrina) in Alberta, by Michael Norton. 20 pp. (2001)

No. 34 Status of the Whooping Crane (Grus americana) in Alberta, by Jennifer L. White. 21 pp. (2001)

No. 35 Status of Soapweed (Yucca glauca) in Alberta, by Donna Hurlburt. 18 pp. (2001)

No. 36 Status of the Harlequin Duck (Histrionicus histrionicus) in Alberta, by Beth MacCallum. 38 pp. (2001)

No. 37 Status of the Grizzly Bear (Ursus arctos) in Alberta, by John L. Kansas. 43 pp. (2002)

No. 38 Status of the Wood Bison (Bison bison athabascae) in Alberta, by Jonathan A. Mitchell and C. Cormack Gates. 32 pp. (2002) 
No. 39 Status of the Bull Trout (Salvelinus confluentus) in Alberta, by John R. Post and Fiona D. Johnston. 40 pp. (2002)

No. 40 Status of the Banff Springs Snail (Physella johnsoni) in Alberta, by Dwayne A.W. Lepitzki. 29 pp. (2002)

No. 41 Status of the Shortjaw Cisco (Coregonus zenithicus) in Alberta, by Mark Steinhilber. 23 pp. (2002)

No. 42 Status of the Prairie Falcon (Falco mexicanus) in Alberta, by Dale Paton. 28 pp. (2002)

No. 43 Status of the American Badger (Taxidea taxus) in Alberta, by Dave Scobie. 17 pp. (2002)

No. 44 Status of the Yucca Moth (Tegeticula yuccasella) in Alberta. Alberta Sustainable Resource Development. 21 pp. (2002)

No. 45 Status of the White-winged Scoter (Melanitta fusca deglandi) in Alberta. Alberta Sustainable Resource Development. 15 pp. (2002)

No. 46 Status of the Lake Sturgeon (Acipenser fulvescens) in Alberta. Alberta Sustainable Resource Development. 30 pp. (2002)

No. 47 Status of the Western Silvery Minnow (Hybognathus argyritis) in Alberta. Alberta Sustainable Resource Development. 24 pp. (2003)

No. 48 Status of the Small-flowered Sand Verbena (Tripterocalyx micranthus) in Alberta. Alberta Sustainable Resource Development. 24 pp. (2003)

No. 49 Status of the Brown Creeper (Certhia americana) in Alberta. Alberta Sustainable Resource Development. 30 pp. (2003)

No. 50 Status of the Mountain Plover (Charadrius montanus) in Alberta. Alberta Sustainable Resource Development. 25 pp. (2003)

No. 51 Status of the St. Mary Shorthead Sculpin (provisionally Cottus bairdi punctulatus) in Alberta. Alberta Sustainable Resource Development. 24 pp. (2003)

No. 52 Status of the Stonecat (Noturus flavus) in Alberta. Alberta Sustainable Resource Development. 22 pp. (2003)

No. 53 Status of the Sage Thrasher (Oreoscoptes montanus) in Alberta. Alberta Sustainable Resource Development. 23 pp. (2004)

No. 54 Status of the Tiny Cryptanthe (Cryptantha minima) in Alberta. Alberta Sustainable Resource Development. 39 pp. (2004)

No. 55 Status of the Slender Mouse-ear-cress (Halimolobos virgata) in Alberta. Alberta Sustainable Resource Development. 27 pp. (2005)

No. 56 Status of the Barred Owl (Strix varia) in Alberta. Alberta Sustainable Resource Development. 15 pp. (2005)

No. 57 Status of the Arctic Grayling (Thymallus arcticus) in Alberta. Alberta Sustainable Resource Development. 41 pp. (2005)

No. 58 Status of the Weidemeyer's Admiral (Limenitis weidemeyerii) in Alberta. Alberta Sustainable Resource Development and Alberta Conservation Association. 13 pp. (2005) 
No. 59 Status of the Porsild's Bryum (Bryum porsildii) in Alberta. Alberta Sustainable Resource Development and Alberta Conservation Association. 30 pp. (2006)

No. 60 Status of the Western Grebe (Aechmophorus occidentalis) in Alberta. Alberta Sustainable Resource Development and Alberta Conservation Association. 28 pp. (2006) 


LIBRARY AND ARCHIVES CANADA 